\title{
Floras of clastic and peat-forming Pennsylvanian wetlands: are they different? A case study from the Upper Radnice Coal (late Duckmantian), Kladno Coalfield, Czech Republic
}

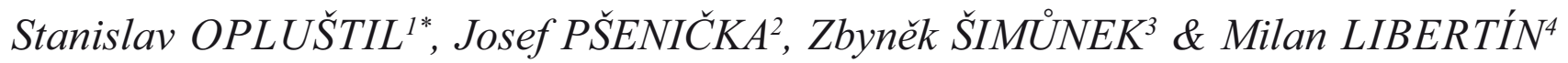

${ }^{1}$ Charles University in Prague, Faculty of Science, Albertov 6, 128 43, Prague 2, Czech Republic; oplustil@natur.cuni.cz

2 Palaeontology Department, West Bohemian Museum in Plzeň, Kopeckého sady 2, 30136 Plzeň, Czech Republic; jpsenicka@zcm.cz

${ }^{3}$ Czech Geological Survey, Klárov 131/3, 11821 Praha 1, Czech Republic; zbynek.simunek@geology.cz

${ }^{4}$ National Museum, Václavské náměstí 68, 11579 Praha 1, Czech Republic; milan_libertin@nm.cz

* Corresponding author

Opluštil, S., Pšenička, J., Šimůnek, Z. \& Libertín, M. 2016. Floras of clastic and peat-forming Pennsylvanian wetlands: are they different? A case study from the Upper Radnice Coal (late Duckmantian), Kladno Coalfield, Czech Republic. [Floras de áreas pantanosas de sustrato siliciclástico y de turbera: ¿son diferentes? Estudio de un caso concreto, el Upper Radnice Coal (Duckmantiense superior), cuenca minera de Kladno, República Checa]. Spanish Journal of Palaeontology, 31 (1), 145-180.

Manuscript received 26 February 2016

Manuscript accepted 14 April 2016

(C) Sociedad Española de Paleontología ISSN 2255-0550

ABSTRACT

Floras of two ecologically and taphonomically different fossiliferous horizons associated with the late Duckmantian Upper Radnice Coal in the Kladno Coalfield are compared. These fossiliferous horizons include the Velká opuka that is $\mathrm{a} \geq 10 \mathrm{~cm}$ thick volcaniclastic parting embedded in the coal and the Mydlák, which is a laminated mudstone in the roof of the same seam. Observations made in coal mines suggest that the Velká opuka bears autochthonous in situ preserved peat-forming vegetation, whereas the Mydlák is a lacustrine sediment that contains mostly drifted allochthonous and locally parautochthonous plant associations derived from coastal mostly clastic wetlands. Material from museum collections and our own field data show that floras of both fossiliferous horizons consist of representatives of the same families and genera but differ in their proportions and to a large part in species composition. This is demonstrated by only $40 \%$ overlap of 89 plant species identified in both horizons. Flora of the Velká opuka is dominated by

\section{RESUMEN}

Se comparan las floras de dos niveles fosilíferos ecológica y tafonónicamente diferentes que están asociados con el Upper Radnice Coal, del Duckmantiense superior de la cuenca minera de Kladno. Estos niveles fosilíferos son el horizonte Velká, $\geq 10 \mathrm{~cm}$ de volcaniclásticos intercalados en el carbón, y el horizonte Mydlák, una lutita laminada a techo de la capa de carbón. Las observaciones hechas en las minas de carbón sugieren que el horizonte Velká contiene la flora autóctona, que se preservó in situ en la turbera, mientras que el Mydlák es un sedimento lacustre que contiene sobre todo restos alóctonos transportados $\mathrm{y}$, localmente, asociaciones parautóctonas procedentes en su mayoría de zonas pantanosas marginales más siliciclásticas. El material de colecciones de museos y nuestras propias observaciones en el campo indican que las floras de ambos horizontes están formadas por representantes de las mismas familias y géneros, auque son diferentes en sus proporciones y en las especies que las componen. Esto se deduce del hecho de que sólo hay un 40 
lycopsids, either by arborescent lepidodendrids or by the sub-arborescent genus Omphalophloios. Co-dominant are sphenopsids and locally common are ferns and cordaitaleans. The Mydlák flora is more diverse and dominated by pteridosperms, whereas the proportion of lycopsids is lower and their composition partly different. Taxa abundant in the Velká opuka and nearly absent in the Mydlák include Omphalophloios feistmantelii, Lepidodendron longifolium and L. ophiurus. Abundant in the Mydlák and mostly missing in the Velká opuka are Laveineopteris tenuifolia, L. bohemica, Sphenopteris spiniformis, Eusphenopteris nummularia, Lepidodendron aculeatum and L. mannebachense. Prevalence of pteridosperms in clastic wetland floras of the Mydlák is in agreement with existing observations.

Keywords: Pennsylvanian, palaeoecology, plant taphonomy, clastic swamp, peat swamp.
$\%$ de solapado de las 89 especies identificadas en ambos horizontes. En la flora de Velká predominan las licópsidas, que pueden ser lepidodendraceas arbóreas o géneros subarbóreos como Omphalophloios. Las esfenópsidas son co-dominantes y, localmente, los helechos y Cordaitales. La flora de Mydlák es más diversa y con predominio de pteridospermas, mientras que la proporción de licópsidas es menor y su composición parcialmente diferente. Los taxones más abundantes en Velká y prácticamente ausentes en el horizonte Mydlák son Omphalophloios feistmantelii, Lepidodendron longifolium y L. ophiurus. Abundantes en Mydlák y prácticamente ausentes en Velká serían Laveineopteris tenuifolia, L. bohemica, Sphenopteris spiniformis, Eusphenopteris nummularia, Lepidodendron aculeatum y L. mannebachense. El predominio de las pteridospermas en las floras de las zonas pantanosas de sustrato siliciclástico de Mydlák está de acuerdo con las observaciones ya existentes.

Palabras clave: Pensilvánico, paleoecología, tafonomía, áreas pantanosas de sustrato siliciclático, zona de turbera.

\section{INTRODUCTION}

The Pennsylvanian subperiod is one of the most important coal-bearing intervals in the Earth history. In the tropics of that time, peat-forming wetlands spread from extensive coastal lowlands far into the interior of the Laurussia and China continents. The entire area covered by the wetland ecosystems is estimated to reach several millions of square kilometres (Cleal \& Thomas, 2005). High preservation potential of the Pennsylvanian wetland flora, dominated by cryptogamic and early seed plants (DiMichele et al., 2010), resulted in its collecting and study since the beginning of systematic coal exploitation in the early $19^{\text {th }}$ century (e.g., Sternberg, 1820-1825; Lindley \& Hutton, 18311837; Brongniart, 1822, 1828-1838). Mostly taxonomic early studies were later extended to other related topics including stratigraphy, palaeoecology and plant diversity (e.g., White, 1912; Davies, 1929; Gothan \& Gimm, 1930; Němejc, 1946; Havlena, 1961; Šetlík, 1977; Wagner, 1984; DiMichele et al., 2002; Falcon-Lang, 2004; Cleal, 2005; Cleal et al., 2012). The fossil record explored in these studies comprises two basic types: plant compressions preserved in siliciclastic sediments, mostly in mudstones, and in petrifactions represented mostly by coal-balls (Scott et al., 1996). Studies of these fossil records revealed longterm ecological stability and conservatism of wetland ecosystems with only minor changes in species composition between individual cyclothems/coal seams during Early to early Middle Pennsylvanian (e.g., DiMichele et al., 2002, 2004, 2010; Cleal et al., 2012; Tabor et al., 2013). Coal-ball studies also showed that tropical peats were dominantly composed of arborescent lycopsids, which comprise $60-90 \%$ of peat volume (Phillips, 1981; Phillips et al., 1985). Their decline around the turn of the Middle and Upper Pennsylvanian was confirmed by a drastic decrease in their volume in coal-balls in favour of tree ferns and is expressed in a similar change in composition of compression floras (Cleal et al., 2010, 2012) and palynomorphs (Peppers, 1996). Other studies further show that Pennsylvanian tropical wetlands were not stable environments in hundreds of square kilometres but consisted of mosaics of various habitats, which differed in the rate and frequency of sediment input, composition of substrate and its saturation by water expressed by water table height and its fluctuation (DiMichele \& Phillips, 1994; Greb et al., 2006; Gastaldo \& Demko, 2011). A basic subdivision was suggested by Gastaldo (1987) who distinguished between clastic and peat-forming wetlands. The floras of these two major habitats are believed to be basically similar, composed of the same plant genera, but differed in species composition and in the proportion of different plant groups (DiMichele et al., 1991, 2010; Cleal et al., 2010, 2012). However, differences in the character of these two forms of plant preservation precludes straightforward comparison. Whereas the flora of clastic wetlands is preserved as compressions showing the outer morphology of species, flora of peat swamps can only be studied where plant tissues were permineralised and preserved in histological detail in coal-balls (Galtier, 1997). Direct comparison is possible only where a roof shale flora preserves the final stage of peat swamp development prior its inundation. However, to recognize the relationship between the site of growth of the vegetation and the place of its burial and in turn the relationship between the roof 
shale flora and an underlying coal (originally peat) requires detailed sedimentological and taphonomical observations (Gastaldo et al., 1995; DiMichele \& Falcon-Lang, 2011).

Another opportunity to study peat-forming floras is provided by volcanic ash bands either within a coal seam or located in its roof. If they are thick enough, i.e. $>10 \mathrm{~cm}$, their deposition over a landscape resulted in severe damage of vegetation and rapid in situ burial of fragmented or leveled plant remains by volcanic ash (Burnham \& Spicer, 1986; Burnham, 1994; Opluštil et al., 2009a, b, 2014). Several examples of such fossil-bearing tuff beds have been described recently from Puertollano, Spain (Wagner, 1989; Wagner \& Álvarez-Vázquez, 2015), Döhlen, Germany (Rössler \& Barthel, 1998; Barthel, 2016), Wuda, China (Wang et al., 2012) and in continental basins of the Czech Republic (Opluštil et al., 2007). These tuff beds preserve in situ floras that can be compared with similarly preserved floras in the roof of the same coal. This is exactly the case of the Upper Radnice Coal of late Duckmantian age (Early Moscovian) in the KladnoRakovník Basin in the central part of the Czech Republic. This up to $10 \mathrm{~m}$ thick coal was mined for two centuries and was accompanied by collecting of fossils from intercalated volcanic band and its roof shale during this same time. Extensive collections from both fossiliferous beds provide an excellent opportunity to compare the floras, both of which are preserved as compressions, despite coming from different kinds of environmental settings. Such a comparison contributes to our understanding of whether and how the floras of peat-forming and clastic habitats taxonomically differ.

\section{GEOLOGICAL SETTING OF THE KLADNO-RAKOVNÍK BASIN}

The Kladno-Rakovník Basin is one of several early postorogenic continental basins (Fig. 1A), which developed in the Bohemian Massif during Pennsylvanian times (Pešek, 1994). The post-orogenic origin of these basins is demonstrated by sub-horizontally inclined unfolded strata. Deposition in the basin was accompanied by acid explosive volcanism resulting from tectono-thermal activity in the amalgamated Bohemian Massif (Žák et al., 2014). As a result a large number of volcaniclastic beds, a few millimetres to $>10 \mathrm{~m}$ thick are intercalated within sediments (Pešek, 1994). In the northern part of the basin close to volcanic centres over a hundred metres thick ignimbrite bodies occur locally.

Fill of the Kladno-Rakovník Basin reaches up to $1440 \mathrm{~m}$ and spans an interval of about 17.1 Ma from late Duckmantian to early Asselian times (Opluštil et al., 2016). Basin fill is dominantly of fluvial origin, although lacustrine, lacustrine delta, peat-swamp and colluvial sediments are also present but to a lesser extent (Pešek, 1994). Typical is a basin-wide alternation of grey coalbearing strata and coal-barren fluvial red beds, the latter with intercalated grey lacustrine horizons in the upper Gzhelian part of the succession (Pešek, 2004; Opluštil et al., 2013). This alternation of sediments was used by Weithofer $(1896,1902)$ for a subdivision into four lithostratigraphic units which are presently called the Kladno, Týnec, Slaný and Líně formations, of which the Kladno and Slaný formations are grey coal-bearing units (Fig. 1B). The Upper Radnice Coal is a part of the Radnice Member (Fig. 1B), the basal unit of the Kladno Formation and the entire basin fill.

\subsection{Radnice Member and the Upper Radnice Coal}

The Radnice Member is of late Duckmantian-early Bolsovian age and represents the Paripteris linguaefolia Zone (Opluštil et al., 2016). Sediments of this unit fill a system of fluvial valleys (Fig. 2) either erosionally incised into Late Proterozoic basement with an inherited palaeotopography of up to few hundred metres or provoked by active faults (Opluštil, 2005a, b). This interpretation explains the irregular distribution of its sediments and its variable thickness from 0 to about $250 \mathrm{~m}$ with maximum values in tectonically-controlled NNE-SSW striking valleys (Pešek, 1994). Besides the predominantly fluvial facies, colluvial deposits are represented by poorly sorted, clast- to matrix-supported slope breccias derived from local basement palaeohighs. Lacustrine and lacustrine deltaic sediments are rare and represented by up to few metres thick intervals located usually in the roof of major coal seams. Coals developed in those valleys where a low clastic input allowed for long-term peat formations, usually along the valley margins protected by small basement ridges against active fluvial channels; however, some coals spread across the entire valley width (Opluštil, 2005b). Coals of the Radnice Member are arranged into the Pilsen, Radnice and Lubná groups; the Radnice group (late Duckmantian) is the most important of these and is developed in most of the palaeovalleys, now representing individual coalfields. It consists of the Lower and Upper Radnice coals separated by a few tens of centimetres to over $10 \mathrm{~m}$ thick Whetstone Horizon which is composed of in situ tuff and redeposited volcaniclastic material mixed with siliciclastics (Mašek, 1973; Opluštil et al., 2014). In the Kladno-Rakovník Basin the Lower Radnice Coal is usually one or two metres thick and composed of high ash coal. The Upper Radnice Coal is thicker and of better quality. In the Kladno Coalfield, where this comparative study is located, the Upper Radnice Coal is usually 6-8 $\mathrm{m}$ thick but reaching locally over $10 \mathrm{~m}$ (Opluštil, 2005b). 


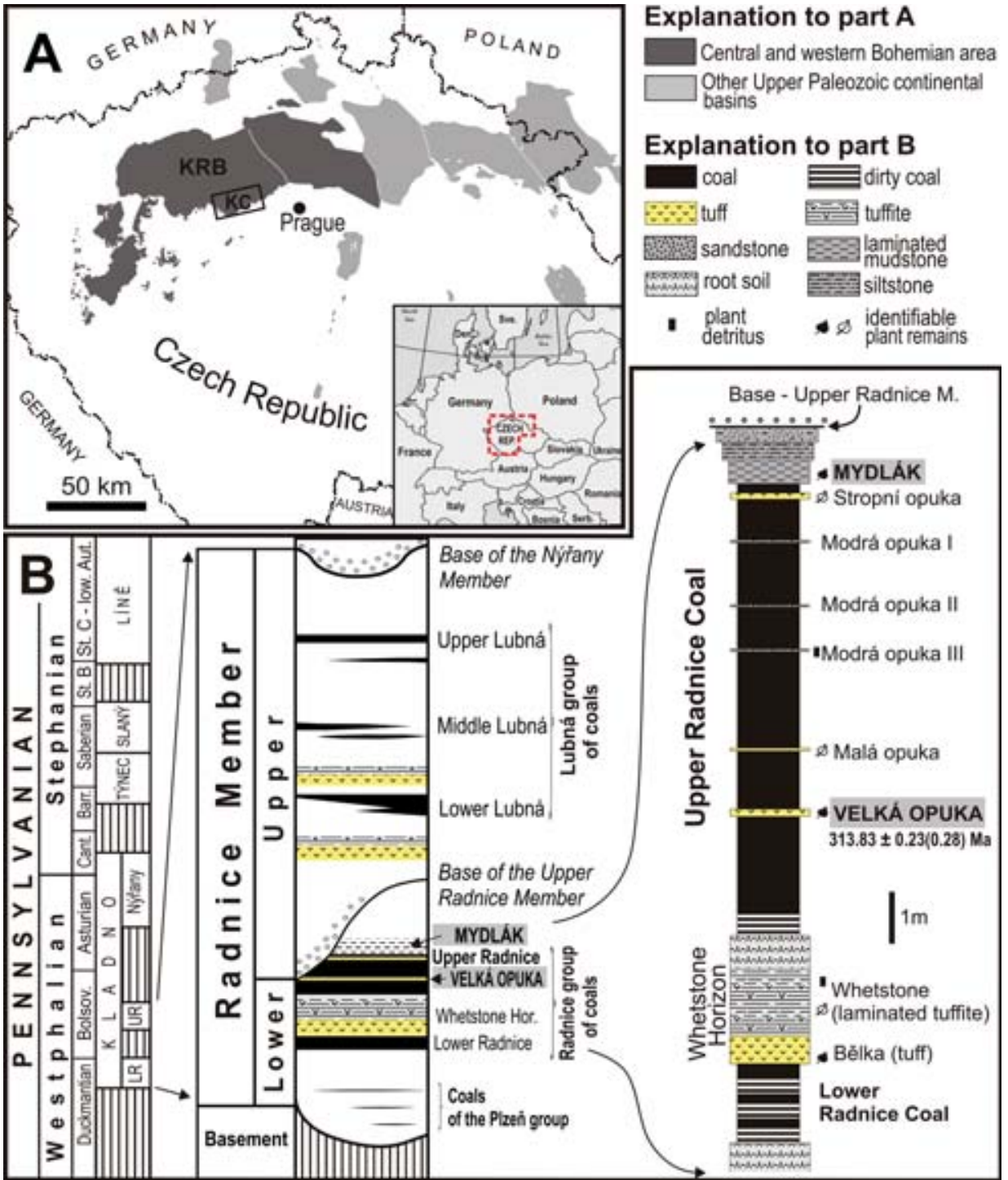

Figure 1. Distribution of Pennsylvanian terrestrial sediments in the Czech Republic and their lithostratigraphic subdivision. A) Position of the Kladno-Rakovník Basin (KRB) within the continental basins of central and western Bohemia with location of the Kladno Coalfield (KC) indicated. B) Lithostratigraphic subdivision of the KladnoRakovník Basin with detail of the Radnice Member and the Radnice coal group.
The coal in this coalfield fills the Kladno Valley, which is the largest palaeovalley of erosional origin in the KladnoRakovník Basin. It strikes W-E, is about $25 \mathrm{~km}$ long. The economically important Upper Radnice Coal originally covered $\sim 19 \mathrm{~km}$ of its length (Fig. 2B). However, a baselevel drop during the newly identified hiatus between the Radnice and Lubná coal groups resulted in deep erosion of the coal and splitting its area into two parts (Opluštil, 2005a; Opluštil et al., 2016). The Upper Radnice Coal covers the 2 to $5 \mathrm{~km}$ wide Kladno Valley nearly "from margin to margin". In plan view this distribution is evident from a very irregular outline of the coal, which nearly faithfully traces the edge of basement palaeohighs along the sides of the Kladno Valley (Fig. 2B). Only along western edge of the coal, where increased sediment input from the source areas disturbed peat accumulation, the Upper Radnice Coal grades into carbonacous mudstone and further out to mudstone representing clastic wetlands (Fig. 2B).
Intercalated in the Upper Radnice Coal are whitish or grey volcaniclastic partings, a few millimetres to over 15 $\mathrm{cm}$ thick, which are traceable across the entire Kladno Coalfield; thicker of these partings also occur in some other coalfields of the Kladno-Rakovník and Radnice basins (Figs 1B, 3A, 4). These ash beds are called "opuky" and serve as excellent correlation markers in the workings of this thick coal (Fig. 3A; Čepek et al., 1936; Orlov, 1942; Mašek, 1973; Mašek \& Pešek, 1979). They represent kaolinized, either in situ deposited or partly reworked volcanic ash beds. The thickest of these, the Velká opuka, bears rich subaerial plant fragments, generally preserved in situ (Opluštil et al., 2007). In the roof of the coal, there is laminated mudstone called "Mydlák", which provides also a rich plant fossil record (Fig. 5). 

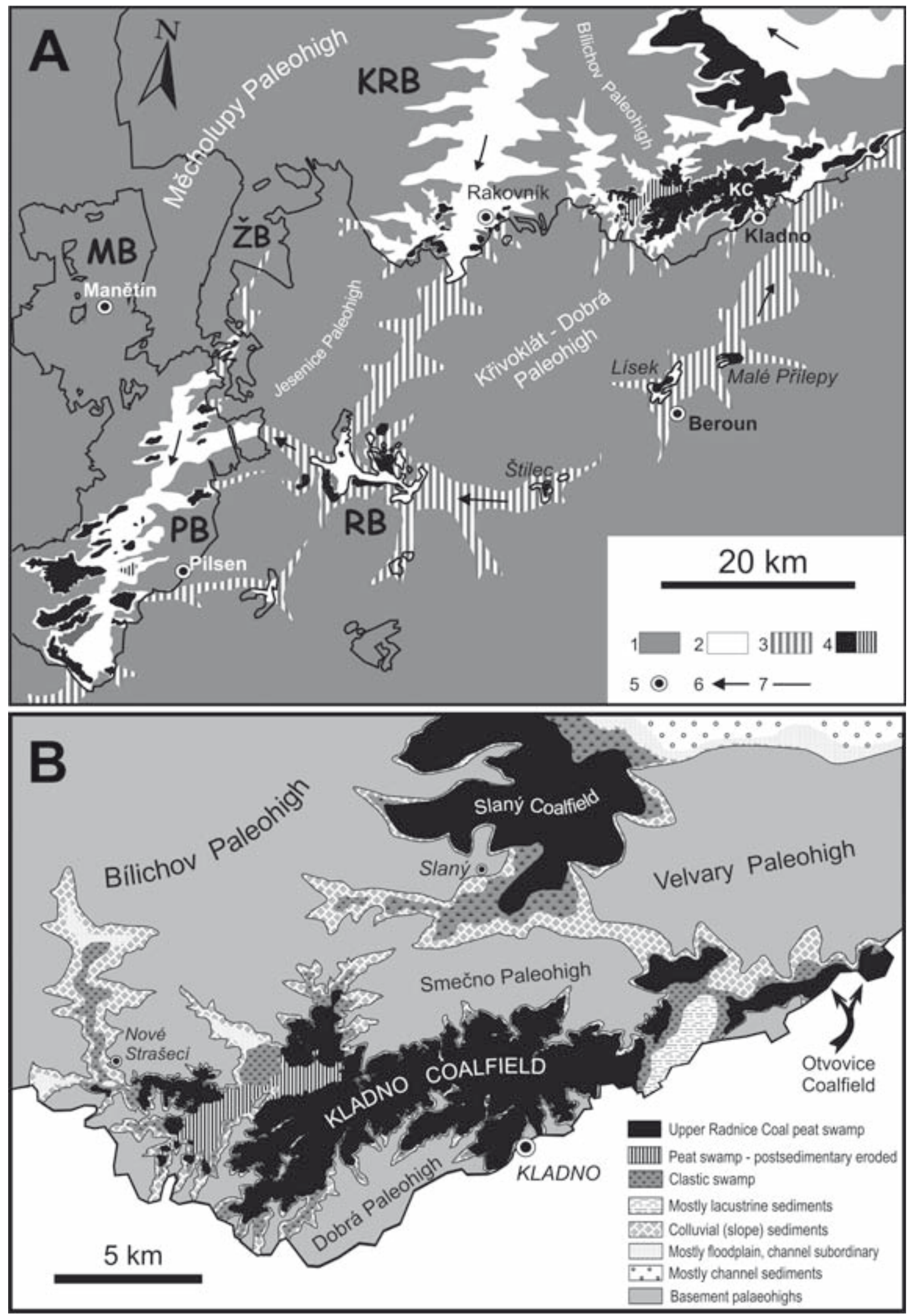

Figure 2. Palaeogeography of the Radnice Member (after Opluštil 2005b, modified). A) Palaeogeography of central and western Bohemia during the formation of the Upper Radnice Coal peat swamp. Explanation of abbreviations and symbols: PB Pilsen Basin, RB - Radnice Basin, MB - Manětín Basin, ŽB - Žihle Basin, KRB - Kladno-Rakovník Basin, KC - Kladno Coalfield, 1 - Basement outcrops, 2 - Current extent of the Lower Radnice Member (LRM), 3 - Assumed distribution of the LRM outside the present-day basin extent, 4 - Upper Radnice Coal peat swamp preserved and eroded post-depositionally, 5 - Towns, 6 - Assumed direction of clastic transport, 7 - Present-day basin margin. B) Palaeogeography of the Kladno Coalfield and its surroundings during the same interval. 

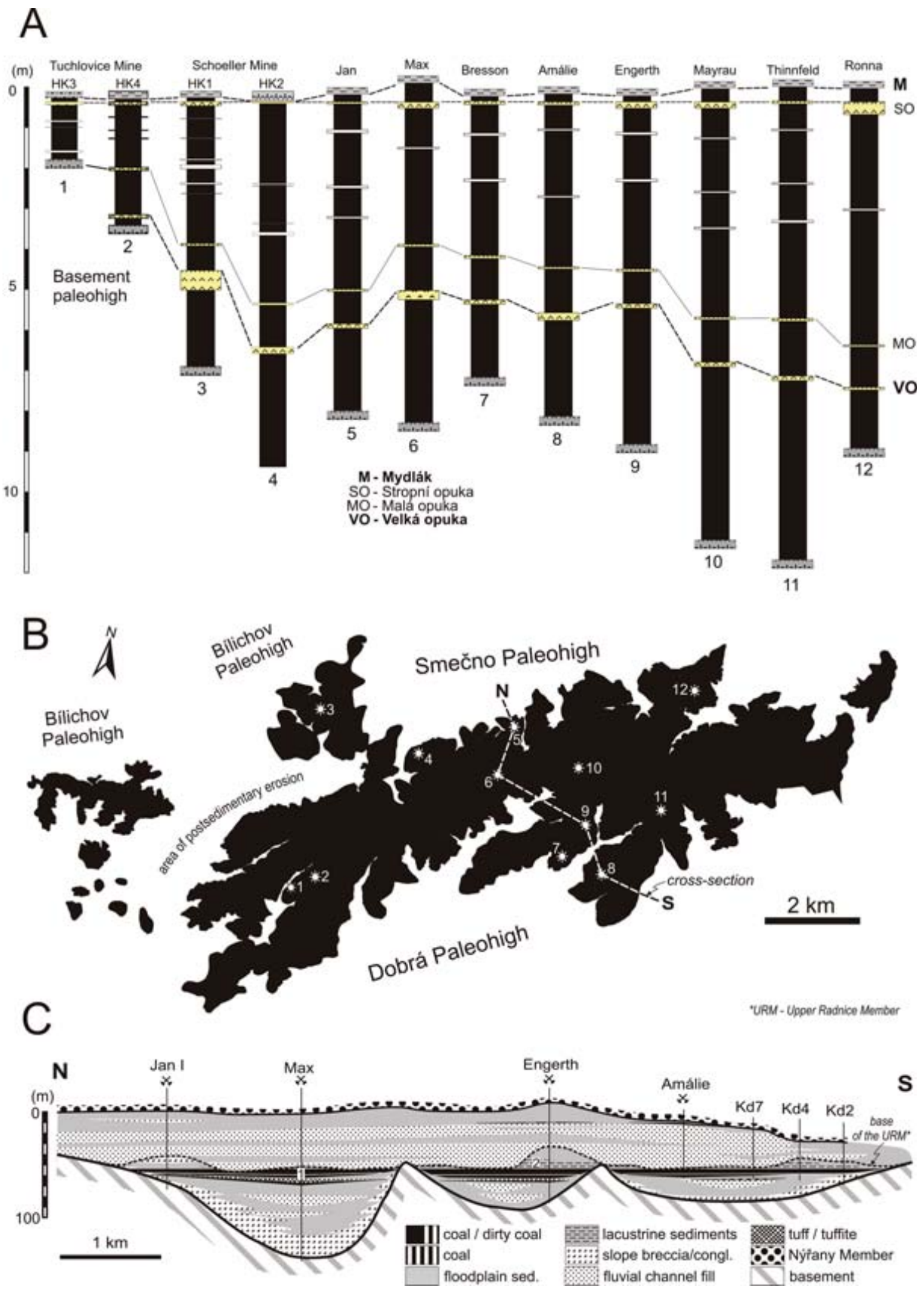

Figure 3. Kladno Coalfield. A) Sections of the Upper Radnice Coal in selected coal mines with location of major sedimentary and volcanic (opuky) partings indicated. For location of sections see numbers in Fig. 3B. B) Present-day extent of the Upper Radnice Coal. C) Cross-section of the Radnice Member in the Kladno Coalfield. Note the prominent pre-existing palaeotopography. 


\section{MATERIAL AND METHODS}

Although the plant fossils preserved in the Upper Radnice Coal roof shale and the Velká opuka were collected in various coalfields ( $\sim$ palaeovalleys) of central and western Bohemia (= central and western Czech Republic), characterization and comparison of the two floras is restricted only to the Kladno Coalfield. This is because this coalfield provided the largest collections from both fossiliferous horizons.

This study is based on extensive field activities of the authors as well as a systematic re-examination of plant fossils in institutional and private collections. Field studies include observations of sedimentological characters of the studied horizons in coal mines since the early 1980 s until the closure of coal mining in 2002. Several tens of excursions into galleries allow conclusions with regard to sedimentology and taphonomy as related in the following chapters. The second part of our field activities included collecting of fossils from these easily identifiable beds on coal mine dumps since the late 70ties until shortly after mine closure. Such long-lasting collecting activity allowed the authors to judge the character and composition of plant fossils in both fossiliferous horizons. Surprisingly, there are some amateur collectors, who successfully continue collecting until present, providing additional material.

For the purpose of our floral studies we have examined several large collections stored in the Chlupáč Museum of Earth History at the Faculty of Science, Charles University in Prague, the National Museum in Prague, West Bohemian Museum in Pilsen, Sládeček Museum in Kladno, and the private collection of Mr. J. Haldovský from Pchery near Kladno. In addition to these primary data from plant collections, we made also a literature search. This included mostly papers of the famous Czech palaeobotanist Prof. F. Němejc (1901/1976), who collected fossils in the Kladno Coalfield for several decades.

Because the main aim of this contribution is to describe the composition of floras and their diversity, not all the morphospecies have been listed. Instead we focused on plant organs which best characterize original biological species. As a result, only one morphotaxon is selected for each biological species. This excludes taxonomic inflation and, thus, expresses more adequately the original plant diversity (Cleal, 2005; Cleal et al., 2012).

The abundance of individual species was estimated only semi-quantitatively as rare, common or abundant since no counts were made in the field.

\section{ORIGIN OF THE "VELKÁ OPUKA" AND "MYDLÁK" AND THE FLORAL TAPHONOMY}

The Velká opuka and Mydlák are two major plant-bearing horizons associated with the Upper Radnice Coal in the Kladno Coalfield of the Kladno-Rakovník Basin. They are of contrasting origin and their fossil records differ in taphonomical history.

\subsection{Velká opuka}

The Velká opuka is a name used by miners and geologists for $\sim 10-20 \mathrm{~cm}$ thick, sharply-based whitish-grey volcaniclastic band intercalated in the lower part of the Upper Radnice Coal and laterally persistent across all coal-mining areas in the Kladno-Rakovník and the Radnice basins (Fig. 4). It is situated usually $\sim 2 \mathrm{~m}$ above the base of the coal; however, this position increases to over $4 \mathrm{~m}$ in the centre of the coalfield, whereas this band can be absent where the lower part of the coal wedges on basement palaeohighs (Fig. 3A). Zircons separated from the Velká opuka provided the CA-ID-TIMS age of $313.83 \pm 0.23$ (0.28) Ma, which corresponds to the latest Duckmantian (Opluštil et al., 2016). Mašek \& Pešek (1979) interpreted the Velká opuka as a massive argilized vitro-crystallic tuff generated by volcanic ash fall. Its upper part may be locally redeposited as indicated by lamination and the presence of plant detritus in areas of increased to anomalous thickness up to $\sim 1 \mathrm{~m}$, where unconsolidated volcanic ash was washed down from the surrounding basement palaeohighs.

It is estimated that the current thickness is about one half or even one third of the original uncompacted volcanic ash bed, covering the landscape (Bohor \& Triplehorn, 1993). Observations of modern volcanic eruptions show that volcanic ash beds of such thickness $(\sim 50 \mathrm{~cm})$ are sufficient to bury the herbaceous groundcover and heavily damage shrubs and trees (Burnham \& Spicer, 1986; Burnham, 1994). Such observations are consistent with the presence of large plant fragments concentrated near the base in the case of herbaceous species (Opluštil et al., 2014). These remains represent a temporally instantaneous, pre-eruption coal-forming flora preserved in situ and in some cases even in growth position as suggested by stumps rooted in coal below the tuff. Upright calamitalean stems show signs of regeneration as indicated by the presence of roots in originally (prior to volcanic ash fall) subaerial part of the stem (Opluštil et al., 2007). Only where the upper part of the ash bed was redeposited and thickened, usually along valley margins in the proximity of basement palaeohighs, it also contains drifted plant detritus with only sparse identifiable plant remains of a compositionally distinct possibly upland flora. Where the thickness of the Velká opuka is not increased by redeposition, it is usually 


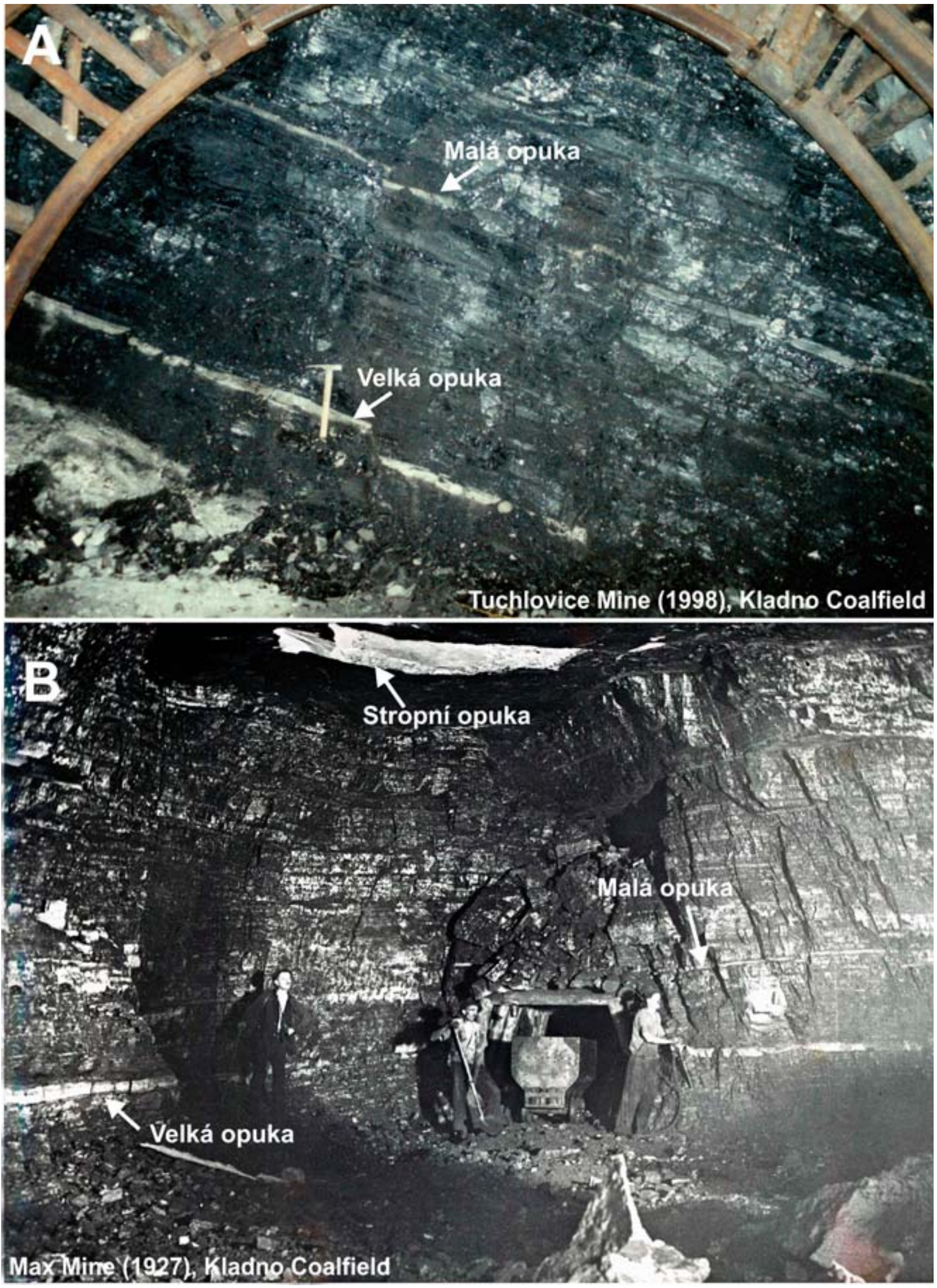

Figure 4. Upper Radnice Coal as exposed in the Tuchlovice (A) and Max (B) mines of the Kladno Coalfield. Arrows indicate several volcaniclastic partings called "opuka". Figure 4B provided by Josef Seifert. 
heavily penetrated by stigmarian rhizomorphs and their appendices, and less frequently by some other types of rooting systems of the post-eruption flora that recolonized the buried peat swamp.

Palynological analysis of the Upper Radnice Coal indicates a transition from the Lycospore to Densospore phases around the level of the Velká opuka (Opluštil et al., 1999). This implies the existence of two contrasting plant associations, the former dominated by Lycosporaproducing lepidodendrid lycopsids and the latter by the sub-arborescent lycopsid Omphalophloios feistmantelii (Bek et al., 2015). This is in agreement with macroflora collected from the Velká opuka in various mines across the entire Kladno Coalfield.

\subsection{Mydlák}

The Mydlák is a name given by miners to an irregularly laminate grey mudstone which overlies the roof of the Upper Radnice Coal in the Kladno Coalfield (Fig. 5) with a sharp contact. Contrary to the Velká opuka, the Mydlák is interpreted as a lacustrine sediment (Opluštil, $2003,2005 a, b)$. It is of variable thickness ranging from a few tens of centimetres to $\sim 7 \mathrm{~m}$ (Havlena, 1964) and irregularly grades upward into fine-grained ripple-bedded sandstone terminated by an erosional surface of regional extent followed by fluvial channel sandstone and/or conglomerates (Fig. 3C). Locally these conglomerates are deeply incised into the Mydlák and even the Upper Radnice Coal below (Opluštil, 2005a). The whole coarsening-up sequence from the base of the Mydlák to the erosional surface is interpreted as a lacustrine delta complex filling the lake formed due to a rise in relative base level (Opluštil, 2005a). Absence of benthic fauna suggests either a high sedimentation rate or anoxic bottom conditions. The contact of Mydlák and the Upper Radnice Coal is sharp and no indications of interruption of deposition have been observed. Roots are absent in the Mydlák except for the marginal areas of the Upper Radnice Coal - deposits of the original lake shallow near the basement palaeohighs. Here, the roots and aerial part of plants occur together and lamination is usually poorly developed or absent. With increasing distance from the lake margin, however, roots disappear and only drifted plant remains occur (Opluštil, 2003). The Mydlák becomes dark grey to grey, thinly bedded and often irregularly laminate mudstone with plant compressions on the bedding planes (Fig. 5). The plant remains consist mainly of identifiable plant fragments of various sizes and lacking any sorting; massive stems being usually crudely- and the fragile foliage finely fragmented. Most plant remains are concentrated in the basal few centimetres, where they often cover bedding planes densely; up-section their density decreases significantly. In the few basal millimetres at the contact of the Mydlák with the underlying coal, the plant fossils often cover most of the bedding plane; however, their coalified remains are usually separated from each other by thin sediment layers. This kind of preservation indicates a transport and coeval deposition of mud from suspension (Gastaldo et al., 1995). Compressions are mainly flat lying. Stems that penetrate sediments diagonally and upright stems are rare. Typical plant assemblages found in the Mydlák consists of $\mathrm{cm}-$ $\mathrm{dm}$ (or even larger) fragments of prostrate calamite stems, pteridosperm and fern axes associated with foliage of the different plant groups. Remains of arborescent lycopsids are usually subordinate elements, represented by isolated leaves, fructifications or fragments thereof, as well as leafy shoot, branch or stem fragments.

Based on our taphonomical and sedimentological field observations the Mydlák is interpreted as a lake sediment, which terminated the formation of the Upper Radnice Coal (Opluštil, 2005a, b). Except for marginal areas, the lake was deep enough to prevent its colonization by plants as indicated by the absence of roots. Alternating deposition of mud and silt from suspension dominated across most parts of the lake except the marginal areas where deposition from density flows as well as traction currents resulted in the deposition of ripple-bedded sand lenses, laminae or even decimetres thick, fairly complex sand bodies (Fig. 5B).

The sharp contact between the coal and the Mydlák suggests relatively fast but probably not catastrophic inundation of the peat swamp as is also suggested by the rare occurrences of upright stems (Gastaldo et al., 1995; DiMichele \& Falcon-Lang, 2011). Differences in coal thickness between the Stropní opuka and the Mydlák (Fig. 3A) as well as between some other isochronous volcanic partings embedded in coal, may indicate an irregular rate of peat accumulation prior to the isochronous inundation of entire peat swamp or a gradual onset of inundation under more or less spatially even peat accretion. Possible explanation is also a palaeotopography of mire with presence of raised-mire areas separated by low-lying topography peat swamp. Currently, no clear data allow a preference for either one of these hypotheses. No evidence of any interruption of deposition between the peat and the Mydlák has been observed. However, the beginning of lacustrine flooding of the peat swamp is traceable back into the coal where a palynological change is observed several tens of centimetres below its roof; this is marked by a transition from a densospore to a lycospore phase (unpublished data of J. Bek and S. Opluštil).

From a taphonomic point of view, the plant fossils preserved in rootless laminate mudstones represent allochthonous flora, drifted in from a relatively short distance of $\sim 2 \mathrm{~km}$ maximum from the lake shore, where roots are common. These rooted shoreline "facies" of the Mydlák bear autochthonous to parautochthonous subaerial plant remains sensu Bateman (1991). The roots provide 

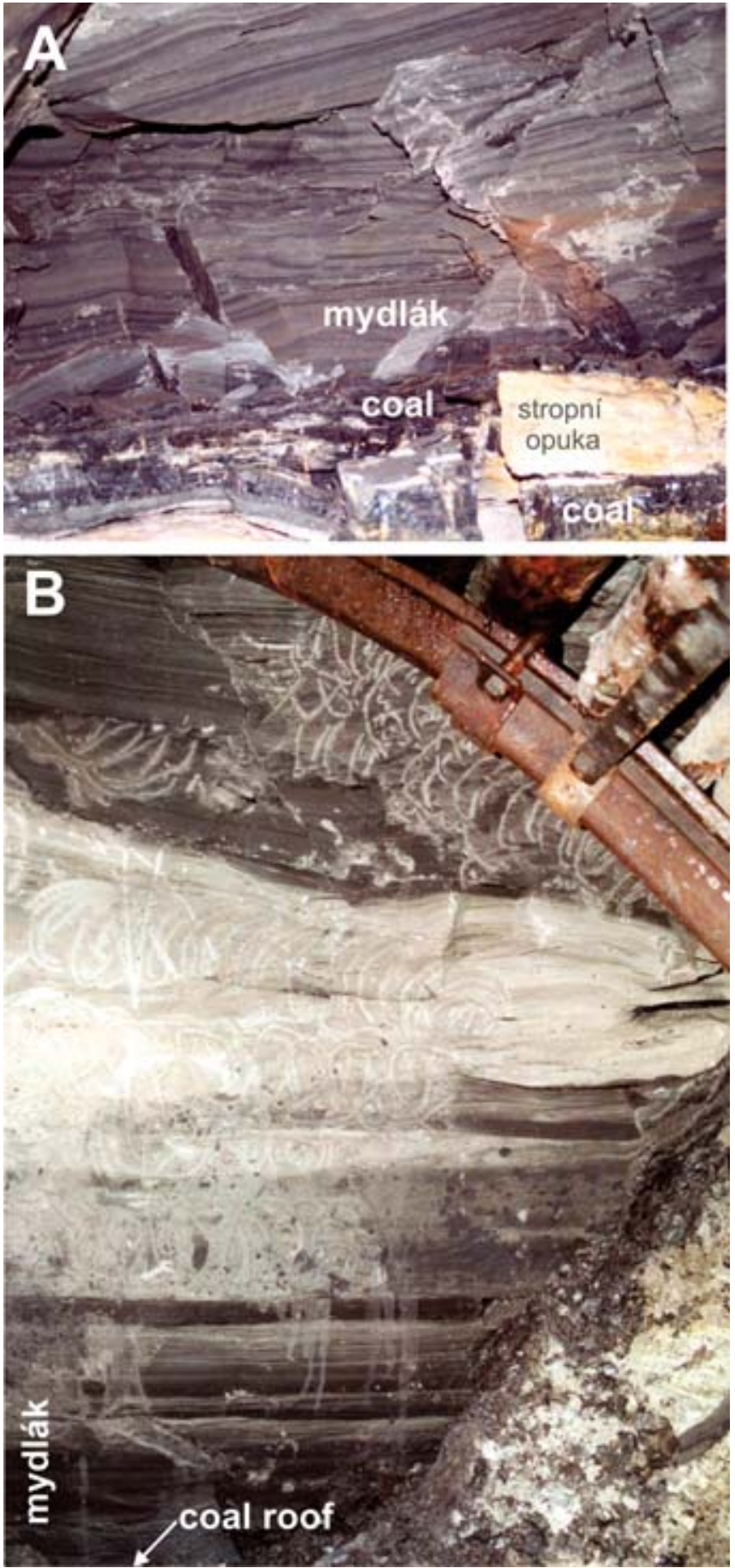

Figure 5. Mydlák horizon in the roof of Upper Radnice Coal. A) Irregularly laminated mudstone overlying the coal with intercalated Stropní (= roof) opuka tonstein, Tuchlovice Mine. Central part of palaeovalley. B) About $3 \mathrm{~m}$ thick part of the overburden of the Upper Radnice Coal as exposed in a gallery of the Tuchlovice Mine close to the margin of palaeovalley. Note the sharp-based thick sand body representing a sudden clastic influx into a lake close to palaeovalley margin. evidence that at least part of the plant remains preserved in the Mydlák is derived from these coastal clastic wetlands, although the presence of relictual plant fossils from the terminal drowning phase of the peat swamp, preserved at or near the contact of the Mydlák and coal, cannot be excluded. However, differences in the species composition of the plant association in the Mydlák and that preserved in the intra-coal Velká opuka suggest drowning of the peat swamp and the gradual establishment of mineral-rich wetlands bordering the lake. The fossil-plant assemblages of these new peri-lacustrine habitats are dominated by sphenopsids, pteridosperms and ferns with subordinate arborescent lycopsids of species that are rare or absent in the Velká opuka.

Decrease in plant fossil content up-section suggests diminishment of wetlands, possibly due to increased clastic input, as the lake was gradually filled in. This is suggested by coarsening of the Mydlák up the section into ripple-bedded fine-grained sandstone followed by the regional erosional surface marking base level drop (Opluštil, 2005a).

\section{PLANT SYSTEMATICS AND BIODIVERSITY}

In all, 89 biological species have been recognized in the Velká opuka and Mydlák together. 59 species of these occur in the Velká opuka and 67 in the Mydlák (Figs $6,7,8)$. Both plant-bearing horizons have 37 species in common, which makes for $\sim 42 \%$ overlap in species composition. This overlap varies between the different plant groups (Figs 7,9). The highest is among sphenopsids, both within calamites and sphenophylls, where about 83 and $80 \%$ overlap exists respectively. In contrast, the lowest number of species in common between the two fossiliferous horizons was found among pteridosperms. Here the overlap within the entire group is $\sim 32 \%$; however, in the case of medullosaleans specifically, this decreases to $22 \%$ (Figs 7,9 ). Low or no overlap exists in case of low-diversity plant groups represented by Noeggerathiales, Cordaitales and Dicranophyllales. They are, however, represented only by one or few species and except for cordaitaleans, their remains are rare. Two or three species of Cordaites were identified based on venation pattern; however, recent cuticular studies of this plant group (Šimůnek \& Haldovský, 2015) have revealed much greater diversity than previously suspected.

A semi-quantitative estimate of frequency of occurrence of the most common species in both fossiliferous horizons shows that their abundance varies significantly between these two horizons (Fig. 6). Besides the common species there are also species that are unique or nearly so for one 
of the horizons examined. In the Velká opuka the highest percentage of species restricted to this band is among ferns (especially Filicales), making up $28 \%$ and c. $20 \%$ for lycopsids. An anomalously high value of $80 \%$ in the case of cordaitaleans is inflated by the systematic cuticular study of their leaves from the Velká opuka (Šimůnek \& Haldovský, 2015) and the absence of such a study in the Mydlák.

There is also a similar set of species unique to the Mydlák. The highest number of species occurring exclusively in this fossiliferous horizon is among pteridosperms with 13 species, making up to $52 \%$. Detailed examination of this group reveals that the Mydlák contains $78 \%$ of medullosaleans taxa, $80 \%$ of Lyginopteridales and $100 \%$ of Callistophytales. A relatively high percentage of species unique to the Mydlák is found among the lycopsids (36\%), with the highest diversity corresponding to arborescent lycopsids where 7 of 19 species ( $37 \%$ ) were identified only from the Mydlák (Figs 6, 7, 8, 9). The diversity within the individual plant groups is described below.

\subsection{Lycopsida}

Lycophytes in the Velká opuka and Mydlák are mainly represented by arborescent lepidodendrids (Bek \& Opluštil, 2004, 2006). Identified so far are the following species: Lepidodendron aculeatum Sternberg, L. mannebachense Presl in Sternberg, L. longifolium Presl in Sternberg, L. lycopodioides Sternberg, L. ophiurus sensu Němejc, 1954 (non Brongniart), L. simile sensu Němejc, 1954 (non Kidston), Bergeria dilatata (Lindley \& Hutton) Álvarez-Vázquez \& Wagner, Lepidophloios laricinus (Sternberg) Sternberg, Lepidophloios acerosus Lindley \& Hutton, Lepidophloios macrolepidotus Goldenberg, and Bothrodendron minutifolium Boulay (Figs 6, 10, 11).

Identification of individual species is based on the morphology of leaf cushions on stem and branches, and where possible, also on the morphology of leaves, cones and their spore contents. Based on these characteristics, the lepidodendrids can be split into several groups, which at least partly correspond to anatomically defined genera as described from coal balls (Bateman et al., 1992; DiMichele $\&$ Bateman, 1992). They include Lepidodendron aculeatum and L. mannebachense with leaf cushions that have infrafoliar parichnos, representing Lepidodendron sensu stricto as understood by Bateman et al. (1992). Leaves of these two species are long and grass-like. Rarely attached microsporangiate cones (Bek \& Opluštil, 2004) bear Lycospora and belong to the genus Lepidostrobus. Lepidodendron aculeatum and L. mannebachense are abundant in the Mydlák, whereas the former species is absent and the latter very rare in the Velká opuka of Kladno Coalfield and elsewhere.
Another long-leaved species, L. longifolium has raised diamond-shaped leaf cushions without infrafoliar parichnos; its leafy shoots often contain cones described by Němejc (1954) as Lepidostrobus cernuus Sternberg. They are either microsporangiate and bear Cappasporites distortus or megasporangiate, containing Cystosporites diabolicus (unpublished data of J. Bek). Anatomically preserved cones with such spores are assigned to the genus Achlamydocarpon (see Bateman et al., 1992). Plants, bearing these cones belong to the anatomically defined genera Synchysidendron and Diaphorodendron (DiMichele \& Bateman, 1992). Lepidodendron (Synchysidendron) longifolium is abundant in the Velká opuka and probably absent from or very rare in the Mydlák.

Leaf cushions of two other species, Lepidodendron simile and Bergeria dilatata are flat and lack infrafoliar parichnos and a differentiated leaf scar. Nearly always attached to stems and branches are short leaves, providing additional character for the recognition of species. Commonly in organic connection to leafy shoots are narrow cylindrical cones of Lepidostrobus lycopodites type (Němejc, 1954), with both megaspores and microspores (Bek \& Opluštil, 1998 and unpublished data). These belong to the genus Flemingites. All these characters fit perfectly the polycarpic genus Paralycopodites Morey \& Morey. Bergeria dilatata and Lepidodendron simile are quite common in both the Velká opuka and Mydlák (Figs 10,11).

Another short-leaved species with flat leaf cushions lacking infrafoliar parichnos is Lepidodendron lycopodioides. Its slender cones resemble those of Flemingites. However, spores remain unrecorded; it is, therefore, currently impossible to prove this generic attribution. This species is very rare in both fossiliferous horizons.

Lepidodendron ophiurus sensu Němejc (1947) is a short-leaved species, bearing short arch-like leaves and small cylindrical microsporangiate cones, Lepidostrobus ronnaensis Bek \& Opluštil, with Lycospora rotunda (Bek \& Opluštil, 2004). The genus Lepidophloios Sternberg is represented by three species: L. laricinus, L. acerosus and L. macrolepidotus. Their remains are common in the Velká opuka as well as in the Mydlák.

Specimens of Sigillaria are generally much less common in comparison to lepidodendrid lycopsids. However, they are quite diverse. Their identification is based solely on bark compressions/impressions and encompasses the following species: Sigillaria diploderma Corda, S. pachyderma Brongniart, S. trigona Sternberg, S. mamillaris Brongniart, S. feistmantelii Geinitz, S. deutschii Brongniart and $S$. polleri Brongniart. Their distribution and "abundance" in individual horizons is expressed in Figure 6

Common in the Velká opuka but very rare in the Mydlák are the remains of the subarborescent lycopsid Omphalophloios feistmantelii (Bek et al., 2015). Locally 


\begin{tabular}{|c|c|c|c|c|c|c|}
\hline & \multirow{2}{*}{\multicolumn{3}{|c|}{ Plant groups }} & \multirow[t]{2}{*}{ Species } & \multicolumn{2}{|c|}{$\begin{array}{c}\text { Upper Radnice } \\
\text { Coal }\end{array}$} \\
\hline & & & & & vo & M \\
\hline 1 & \multirow{25}{*}{ Lycopsida } & \multirow{19}{*}{\multicolumn{2}{|c|}{ Arborescent }} & Lepidodendron aculeatum & 0 & $\mathrm{XX}$ \\
\hline 2 & & & & Lepidodendron mannebachense & $\mathrm{x}$ & $\mathrm{XX}$ \\
\hline 3 & & & & Lepidodendron longifolium & XXX & $\mathrm{x}$ \\
\hline 4 & & & & Lepidodendron ophiurus & $\mathrm{XX}$ & $\mathrm{x}$ \\
\hline 5 & & & & Bergeria dilatata & $\mathrm{XX}$ & $\mathrm{XX}$ \\
\hline 6 & & & & Lepidodendron simile & $\mathrm{XX}$ & $\mathrm{X}$ \\
\hline 7 & & & & Lepidodendron lycopodioides & $\mathrm{x}$ & $\mathrm{x}$ \\
\hline 8 & & & & Lepidophloios acerosus & $\mathrm{X}$ & $\mathrm{X}$ \\
\hline 9 & & & & Lepidophloios laricinus & $\mathrm{X}$ & $\mathrm{XX}$ \\
\hline 10 & & & & Lepidophloios macrolepidotus & 0 & $\mathrm{x}$ \\
\hline 11 & & & & Bothrodendron minutifolium & 0 & $\mathrm{X}$ \\
\hline 12 & & & & Sigillaria diploderma & $\mathrm{X}$ & $\mathrm{X}$ \\
\hline 13 & & & & Sigillaria polleri & 0 & $\mathrm{X}$ \\
\hline 14 & & & & Sigillaria cf. deutschii & 0 & $\mathrm{X}$ \\
\hline 15 & & & & Sigillaria scutellata & 0 & $\mathrm{X}$ \\
\hline 16 & & & & Sigillaria feistmantelii & $\mathrm{X}$ & 0 \\
\hline 17 & & & & Sigillaria mamillaris & $\mathrm{x}$ & $\mathrm{X}$ \\
\hline 18 & & & & Sigillaria pachyderma & $\mathrm{X}$ & $\mathrm{X}$ \\
\hline 19 & & & & Sigillaria trigona & $\mathrm{X}$ & 0 \\
\hline 20 & & \multirow{4}{*}{\multicolumn{2}{|c|}{ Subarborescent }} & Omphalophloios feistmantelii & XXX & $\mathrm{x}$ \\
\hline 21 & & & & Spencerites chalonerii & $\mathrm{X}$ & 0 \\
\hline 22 & & & & Polysporia robusta & $\mathrm{X}$ & 0 \\
\hline 23 & & & & Polysporia rothwellii & 0 & $\mathrm{x}$ \\
\hline 24 & & \multirow{2}{*}{\multicolumn{2}{|c|}{ Herbaceous }} & Selaginella sp. & 0 & $\mathrm{x}$ \\
\hline 25 & & & & Selaginella labutae & $\mathrm{x}$ & 0 \\
\hline 26 & \multirow{11}{*}{ Sphenopsida } & \multirow{6}{*}{ Calamitaceae } & \multirow{6}{*}{ Leafy shoots } & Annularia radiata & $\mathrm{x}$ & XXX \\
\hline 27 & & & & Annularia pseudostellata & $\mathrm{X}$ & $\mathrm{X}$ \\
\hline 28 & & & & Asterophyllites grandis & XXX & $\mathrm{XXX}$ \\
\hline 29 & & & & Asterphyllites charaeformis & 0 & $\mathrm{XXX}$ \\
\hline 30 & & & & Asterophyllites equisetiformis & $\mathrm{X}$ & $\mathrm{XX}$ \\
\hline 31 & & & & Asterophyllites longifolius & $\mathrm{XX}$ & $\mathrm{XX}$ \\
\hline 32 & & \multirow{5}{*}{ Sphenophyllales } & & Sphenophyllum priveticense & $\mathrm{XX}$ & $\mathrm{XXX}$ \\
\hline 33 & & & & Sphenophyllum myriophyllum & $\mathrm{X}$ & XXX \\
\hline 34 & & & & Sphenophyllum cuneifolium & $\mathrm{X}$ & XX \\
\hline 35 & & & & Sphenophyllum pseudoaquense & $\mathrm{XX}$ & 0 \\
\hline 36 & & & & Sphenophyllum taylorii & $\mathrm{XX}$ & $\mathrm{X}$ \\
\hline 37 & \multirow{8}{*}{ Pteridopsida } & \multirow{4}{*}{ Marattiales } & & Pecopteris abbreviata & 0 & $\mathrm{X}$ \\
\hline 38 & & & & Pecopteris miltonii & 0 & $\mathrm{X}$ \\
\hline 39 & & & & Pecopteris aspidioides & $\mathrm{XX}$ & $\mathrm{XXX}$ \\
\hline 40 & & & & Pecopteris incerta & 0 & $\mathrm{X}$ \\
\hline 41 & & \multirow{4}{*}{ Zygopteridales } & & Desmopteris alethopteroides & $\mathrm{X}$ & 0 \\
\hline 42 & & & & Desmopteris longifolia & $\mathrm{XX}$ & $\mathrm{x}$ \\
\hline 43 & & & & Corynepteris sternbergii & $\mathrm{XXX}$ & $\mathrm{X}$ \\
\hline 44 & & & & Corynepteris coralloides & 0 & $\mathrm{x}$ \\
\hline
\end{tabular}




\begin{tabular}{|c|c|c|c|c|c|c|}
\hline 45 & \multirow{10}{*}{ Pteridopsida } & \multirow{10}{*}{ Filicales } & \multirow{2}{*}{ Tedeleaceae } & Senftenbergia pennaeformis & 0 & $\mathrm{X}$ \\
\hline 46 & & & & Senftenbergia plumosa & $\mathrm{XX}$ & XXX \\
\hline 47 & & & \multirow{2}{*}{ Sermayaceae } & Oligocarpia gutbieri & $\mathrm{X}$ & $\mathrm{X}$ \\
\hline 48 & & & & Oligocarpia lindsaeoides & XX & 0 \\
\hline 49 & & & \multirow{6}{*}{ Incertae sedis } & Hymenotheca globullifera & $\mathrm{X}$ & 0 \\
\hline 50 & & & & Renaultia rotundifolia & 0 & $\mathrm{x}$ \\
\hline 51 & & & & Discopteris vuellersii & $\mathrm{x}$ & 0 \\
\hline 52 & & & & Sphenopteris (Boweria) schatzlarensis & $\mathrm{XX}$ & $\mathrm{XX}$ \\
\hline 53 & & & & Zeilleria delicatula & 0 & $\mathrm{XX}$ \\
\hline 54 & & & & Sphenopteris (Zeilleria) haidingerii & $\mathrm{x}$ & 0 \\
\hline 55 & \multirow{22}{*}{$\begin{array}{c}\text { Pterido- } \\
\text { spermopsida }\end{array}$} & \multirow{9}{*}{ Medullosales } & & Alethopteris distantinervosa & 0 & $\mathrm{X}$ \\
\hline 56 & & & & Alethopteris cf. serlii & 0 & $\mathrm{X}$ \\
\hline 57 & & & & Laveineopteris loshii & $\mathrm{x}$ & $\mathrm{x}$ \\
\hline 58 & & & & Laveineopteris bohemica & 0 & XXX \\
\hline 59 & & & & Laveineopteris tenuifolia & 0 & XXX \\
\hline 60 & & & & Macroneuropteris scheuchzeri & 0 & $\mathrm{X}$ \\
\hline 61 & & & & Havlenaea "Mixoneura" praeovata & 0 & $\mathrm{x}$ \\
\hline 62 & & & & Linopteris neuropteroides f. major & $\mathrm{x}$ & $\mathrm{X}$ \\
\hline 63 & & & & Paripteris linguaefolia & 0 & $\mathrm{XX}$ \\
\hline 64 & & \multirow{2}{*}{ Callistophytales } & & Mariopteris muricata & 0 & $\mathrm{x}$ \\
\hline 65 & & & & Fortopteris radnicensis & 0 & $\mathrm{x}$ \\
\hline 66 & & \multirow{5}{*}{ Lyginopteridales } & & Eusphenopteris nummularia & $\mathrm{x}$ & XXX \\
\hline 67 & & & & Eusphenopteris obtusiloba & 0 & $\mathrm{XX}$ \\
\hline 68 & & & & Eusphenopteris neuropteroides & 0 & $\mathrm{x}$ \\
\hline 69 & & & & Eusphenopteris sauveurii & 0 & $\mathrm{X}$ \\
\hline 70 & & & & Eusphenopteris schumannii & 0 & $\mathrm{x}$ \\
\hline 71 & & \multirow{6}{*}{\multicolumn{2}{|c|}{ Incertae sedis }} & Palmatopteris furcata & $\mathrm{XX}$ & $\mathrm{XX}$ \\
\hline 72 & & & & Sphenopteris spiniformis & $\mathrm{x}$ & XXX \\
\hline 73 & & & & Sphenopteris spinosa & $\mathrm{x}$ & $\mathrm{X}$ \\
\hline 74 & & & & Sphenopteris mixta & $\mathrm{X}$ & $\mathrm{XX}$ \\
\hline 75 & & & & Sphenopteris pulchrior & $\mathrm{XX}$ & 0 \\
\hline 76 & & & & Sphenopteris flexuosissima & XXX & $\mathrm{x}$ \\
\hline 77 & \multirow{7}{*}{$\begin{array}{l}\text { Progymno- } \\
\text { spermopsida }\end{array}$} & \multirow{7}{*}{ Noeggerathiales } & \multirow{2}{*}{ Noeggerathiaceae } & Noeggerathia foliosa & $\mathrm{x}$ & $\mathrm{x}$ \\
\hline 78 & & & & Noeggerathia intermedia & $\mathrm{x}$ & 0 \\
\hline 79 & & & \multirow{5}{*}{ Discinitaceae } & Palaeopteridium macrophyllum & $\mathrm{x}$ & 0 \\
\hline 80 & & & & Palaeopteridium reussii & 0 & $\mathrm{x}$ \\
\hline 81 & & & & Rhacopteris elegans & $\mathrm{x}$ & 0 \\
\hline 82 & & & & Rhacopteris bipinata & $\mathrm{x}$ & 0 \\
\hline 83 & & & & Rhacopteris speciosa & $\mathrm{x}$ & 0 \\
\hline 84 & \multirow{6}{*}{ Pinopsida } & \multirow{5}{*}{ Cordaitales } & \multirow{5}{*}{ Cordaitaceae } & Cordaites kladnoensis & $\mathrm{XX}$ & 0 \\
\hline 85 & & & & Cordaites latus & $\mathrm{X}$ & 0 \\
\hline 86 & & & & Cordaites theodorii & $\mathrm{X}$ & 0 \\
\hline 87 & & & & Cordaites wartmannii & XXX & 0 \\
\hline 88 & & & & Cordaites sp. & $\mathrm{X}$ & $\mathrm{XX}$ \\
\hline 89 & & Dicranophyllales & Dicranophyllaceae & Dicranophyllum dominii & $\mathrm{X}$ & 0 \\
\hline & & & & Estimated number of biological species & 59 & 67 \\
\hline & & Estimat & umber of biological & pecies (without very rare and uncertain) & 40 & 48 \\
\hline & & & Total nur & er of biological species in both horizons & & \\
\hline
\end{tabular}

Relative frequency of occurrence: XXX - abundant, XX - common, $\mathrm{X}$ - rare, $\mathrm{x}$ - very rare or exceptional.

Figure 6. List of species identified so far in the Velká opuka and Mydlák and an estimation of their relative abundance. 
common in this volcanic parting are also representatives of the genera Spencerites (Scott) and Polysporia Newberry (Drábková et al., 2004; Bek et al., 2009a). On the other hand, herbaceous lycopsids are very rare in both plantbearing horizons. They are represented by the genus Selaginella (Bek et al., 2009b and unpublished data).

\subsection{Sphenopsida}

Sphenophytes of the studied horizons are represented by calamitaleans and sphenophylls (Fig. 6). Species diversity of calamitaceans seems to be best estimated from their foliage, although cone and stem species were also identified (Figs 12,13). The following species of calamite leafy shoots were identified: Annularia radiata (Brongniart) Sternberg, A. pseudostellata Potonié, Asterophyllites grandis (Sternberg) Geinitz, A. charaeformis (Sternberg) Unger, A. equisetiformis Brongniart and A. longifolius (Sternberg) Brongniart. The number of foliage taxa is comparable with "stem" taxa as well as with diversity of calamite cones (Němejc, 1953). There is an apparent overlap in species diversity between the Velká opuka and Mydlák; except for Asterophyllites charaeformis, all species occur at both horizons. Calamites are known by their extensive range of ecological adaptability ranging from clastic to peat substrates (e.g., DiMichele, 2014), and including stressful habitats.

Herbaceous sphenophytes are represented by the genus Sphenophyllum Brongniart. Identified were following species: Sphenophyllum cuneifolium (Sternberg) Zeiller, $S$. priveticense Libertín et al., S. myriophyllum Crépin, $S$. taylorii Bek et al. and S. pseudoaquense Libertín et al. (Fig. 6). Four of these are common for both horizons, whereas only $S$. pseudoaquense has been so far found in the Velká opuka.

\subsection{Pteridopsida}

Ferns of the studied horizon are represented by eusporangiate as well as leptosporangiate forms. They belong to the following groups: Marattiales, Zygopteridales and Filicales (Figs 6, 7, 14, 15). Eusporangiate ferns have been identified following artificial foliage species assigned to the Marattiales: Pecopteris abbreviata Brongniart, $P$. miltonii (Artis) Brongniart, $P$. aspidioides Sternberg and Pecopteris incerta Corsin. Pecopteris incerta is probably identical with Pecopteris aspidioides but this can be confirmed only by detailed systematic revision in the future. Similarly Pecopteris miltonii and P. aspidioides show very similar pinnules, which make their correct identification problematic, especially if only fragments of ultimate pinnae are available. Both species had large fronds with a considerable amount of morphological variation that has not been precisely documented up to date as mentioned by Wagner \& Álvarez-Vázquez (2016). It results in lot of confusions in understanding of both species. Pšenička et al. (2009) strictly separated both species and assigned them within the genus Lobatopteris whereas Wagner \& ÁlvarezVázquez (2016) synonymized both species and putted them to the genus Pecopteris. This concept, however, is based only upon assumptions rather than exact data. The holotype of Pecopteris aspidioides comes from the Radnice Basin and Wagner \& Álvarez-Vázquez (2016) unfortunatelly ignored additional material from the type locality, where hundred of specimens, even large than the holotype and including fertile material, are available. These specimens show large pinnule variability depending on position on frond. The main difference can be found in venation, where pinnules of $P$. aspidioides show besides once to twice bifurcated lateral veins also simple veins, while pinnules of $P$. miltonii show twice (rarelly once) bifurcated veins. Another important difference is in shape of proximal part of penultimate pinna, which is acute in case of $P$. miltonii, while $P$. aspidioides has acuminate tip of pinna. Mentioned should be also different type of synangia; $P$. aspidioides bears 4-5 (commonly 5) sporangia per synangium while P. miltonii bears only 3-4 (commonly 4) sporangia per synangium. Based on these facts we keep P. miltonii and $P$. aspidioides as separate species. Nevertheless, detailed taxonomic revision is necessary in future. Marattialean foliage of the studied horizons thus probably represents only three biological species of the subfamily Miltonoide with typical lobatopterid venation pattern (Wagner, 1958; Pšenička \& Bek, 2009). Marattialean ferns are interpreted as colonizers of wet substrates (Lesnikowska, 1989; DiMichele \& Phillips, 2002) as well as moderately welldrained soils (DiMichele \& Phillips, 2002). Marattialean ferns are known from the Velká opuka and Mydlák, but only $P$. aspidioides is abundant in both horizons. In the Velká opuka consists a part of an in situ preserved, preeruption, peat-forming phytocoenosis. In contrast, an allochthonous association of $P$. abbreviata, $P$. aspidioides and P. miltonii in the Mydlák is derived from lake-margin wetlands where they likely colonized various habitats.

Zygopterids are represented by Desmopteris alethopteroides (Ettingshausen) Stur, Desmopteris longifolia (Sternberg in Goeppert) Stur, Corynepteris sternbergii (Ettingshausen) Zeiller and Corynepteris coralloides (Gutbier) Zeiller (Fig. 6). These differ from filicalean as well as marattialean ferns in architecture, anatomy and reproductive organs (Phillips \& Galtier, 2005). There is a nomenclatural and taxonomic problem with Corynepteris angustissima and Asplenites (Corynepteris) sternbergii. Pecopteris (Corynepteris) angustissima was established by Sternberg (1825) based on material from Svinná locality (tuff bed at the base of the Whetstone Horizon, Radnice Member). Later, Ettingshausen (1854) established a new species Asplenites (Corynepteris) sternbergii based on material from the same locality and 


\begin{tabular}{|c|c|c|c|c|c|c|c|c|c|}
\hline \multirow[t]{2}{*}{ Species $\nabla$ / Horizons $\nabla$} & \multirow{2}{*}{$\begin{array}{c}\text { Number } \\
\text { of } \\
\text { species }\end{array}$} & \multicolumn{3}{|c|}{ Velká opuka } & \multicolumn{3}{|c|}{ Mydlák } & \multirow{2}{*}{$\begin{array}{l}\text { Common } \\
\text { species }\end{array}$} & \multirow[t]{2}{*}{$\%$} \\
\hline & & Total & $\begin{array}{l}\text { Only } \\
\text { Vo }\end{array}$ & $\%$ & Total & $\begin{array}{c}\text { Only } \\
\text { Mydlák }\end{array}$ & $\%$ & & \\
\hline Arborescent lycopsids & 19 & 13 & 2 & 10,5 & 17 & 6 & 31,6 & 11 & 57,9 \\
\hline Sub-arborescent lycopsids & 4 & 3 & 2 & 50,0 & 2 & 1 & 25,0 & 1 & 25,0 \\
\hline Herbaceous lycopsids & 2 & 1 & 1 & 50,0 & 1 & 1 & 50,0 & 0 & 0,0 \\
\hline Lycopsida (total) & 25 & 17 & 5 & 20,0 & 20 & 8 & 32,0 & 12 & 48,0 \\
\hline Calamitaceae & 6 & 5 & 0 & 0,0 & 6 & 1 & 16,7 & 5 & 83,3 \\
\hline Sphenophyllales & 5 & 5 & 1 & 20,0 & 4 & 0 & 0,0 & 4 & 80,0 \\
\hline Sphenopsida (total) & 11 & 10 & 1 & 9,1 & 10 & 1 & 9,1 & 9 & 81,8 \\
\hline Marattiales & 4 & 1 & 0 & 0,0 & 4 & 3 & 75,0 & 1 & 25,0 \\
\hline Zygopteridales & 4 & 3 & 1 & 25,0 & 3 & 1 & 25,0 & 2 & 50,0 \\
\hline Filicales & 10 & 7 & 4 & 40,0 & 6 & 3 & 30,0 & 3 & 30,0 \\
\hline Pteridopsida (total) & 18 & 11 & 5 & 27,8 & 13 & 7 & 38,9 & 6 & 33,3 \\
\hline Medullosales & 9 & 2 & 0 & 0,0 & 9 & 7 & 77,8 & 2 & 22,2 \\
\hline Callistophytales & 2 & 0 & 0 & 0,0 & 2 & 2 & 100,0 & 0 & 0,0 \\
\hline Lyginopteridales & 5 & 1 & 0 & 0,0 & 5 & 4 & 80,0 & 1 & 20,0 \\
\hline Pteridosperms Incertae sedis & 6 & 6 & 1 & 16,7 & 5 & 0 & 0,0 & 5 & 83,3 \\
\hline Pteridospermopsida (total) & 22 & 9 & 1 & 4,5 & 21 & 13 & 59,1 & 8 & 36,4 \\
\hline Noeggerathiales & 7 & 6 & 5 & 71,4 & 2 & 1 & 14,3 & 1 & 14,3 \\
\hline Cordaitales & 5 & 5 & 4 & 80,0 & 1 & $\mathbf{0}$ & $\mathbf{0 , 0}$ & 1 & 20,0 \\
\hline Dicranophyllales & 1 & 1 & 1 & 100,0 & $\mathbf{0}$ & $\mathbf{0}$ & $\mathbf{0 , 0}$ & $\mathbf{0}$ & $\mathbf{0 , 0}$ \\
\hline Species in total & 89 & 59 & 22 & 24,7 & 67 & 30 & 33,7 & 37 & 41,6 \\
\hline
\end{tabular}

Figure 7. Diversity of the Velká opuka and Mydlák floras with regard to systematic groups.

layer like the Sternberg's specimen. From this point of view both species represent the same taxon and must be synonimized. Nevertheless, later many authors described under the names Corynepteris angustissima or $C$. sternbergii different zygopterid species (e.g., Zeiller, 1899; Galtier \& Scott, 1979). Galtier \& Scott $(1979$, p. 12) revised C. sternbergii and incorrectly compared Ettingshausen's specimen with well preserved Kidston's specimens, which represents a different species. The main difference between both species is in type of reproductive organs where Sternberg's C. angustissima has "Biscalitheca" type of sporangia (unpublished observation), while $C$. sternbergii sensu Galtier \& Scott (1979) has typical "Corynepteris" type of sporangia. The problem is that species similar to $C$. sternbergii sensu Galtier \& Scott (1979) were described as C. angustissima or C. sternbergii in many palaeobotanical papers. Specimens from the Velká opuka and Mydlák lack the Biscalitheca type of sporangia and for that reason we use the name C. sternbergii sensu Galtier \& Scott (1979).

Zygopterids formed lush underbrush and also were able to climb on trees (Opluštil et al., 2009a, b). Their morphological and inferred physiological attributes suggest their adaptation to relatively drier and sunny environments (Phillips \& Galtier, 2005). Dennis (1974) and Phillips \& Galtier (2005) inferred from rhizome apices and frond primordia that zygopterids had a capacity for arrested growth responses or dormancy. Evidence of dormancy, in particular, suggests that these ferns were adapted to some limiting factors of habitat regarding water stress (Phillips $\&$ Galtier, 2005). Higher species diversity and frequency of occurrence correspond to the peat-forming assemblage in the Velka opuka. Similar observations were made in the Berlka tuff bed in the roof of the Lower Radnice Coal, which also carries in situ preserved peat-swamp plant taphocoenoses, with an understory characterized by zygopterid ferns (Opluštil et al., 2009a, b). Presence of these plants in the peat substrate may indicate instability of water table.

Leptosporangiate ferns are represented by several taxa of the following filicalean families: Tedeleaceae: Senftenbergia plumosa (Artis) Stur and S. pennaeformis (Brongniart) Stur; Sermayaceae: Oligocarpia gutbieri 


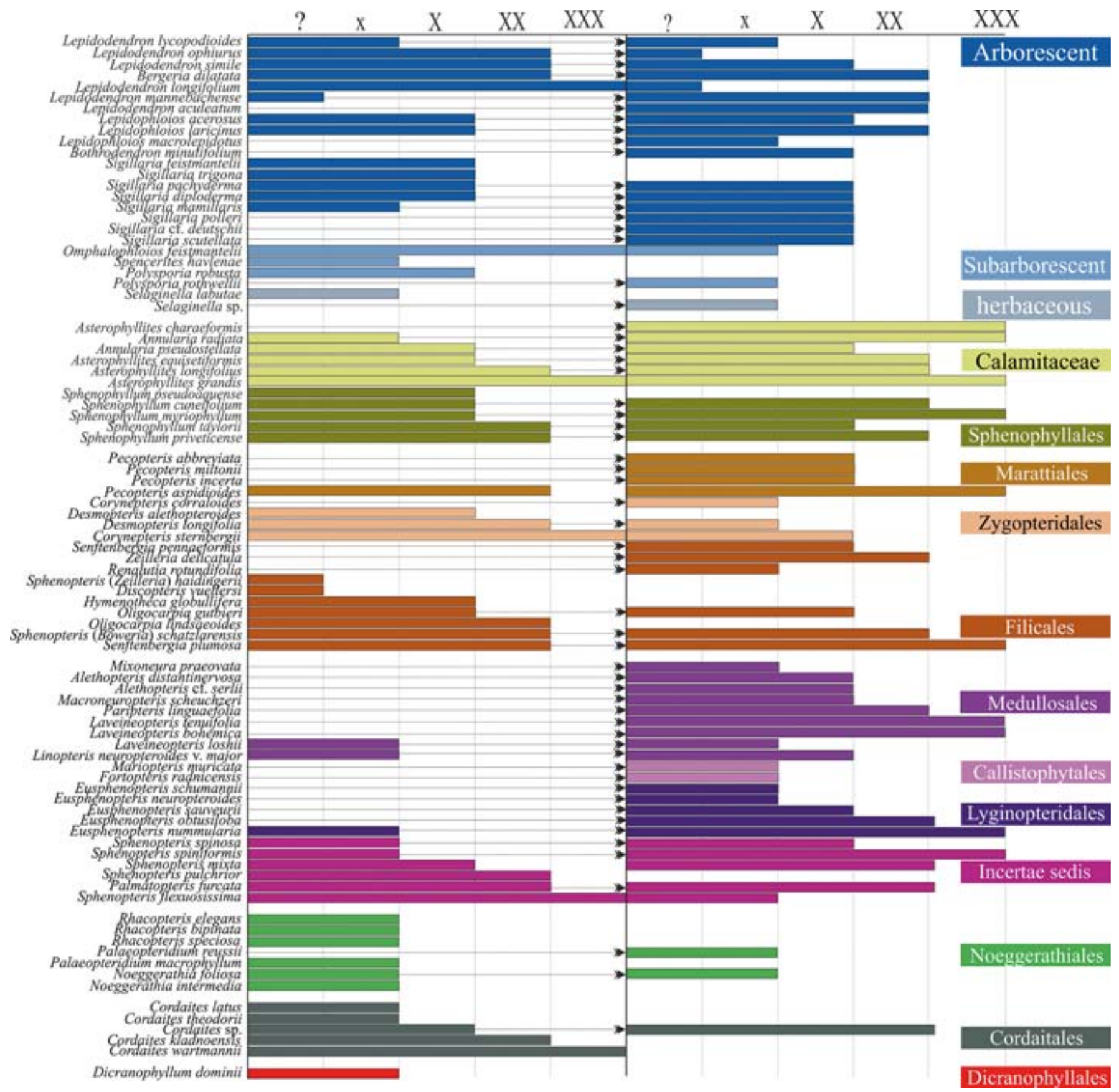

Figure 8. Semiquantitative distribution of species identified from the Velká opuka and Mydlák in the Kladno Coalfield.

Goeppert and O. lindsaeoides (Ettingshausen) Stur; and others, the systematic classification of which remains still unclear: Hymenotheca globulifera Němejc, Renaultia rotundifolia (Andrae) Zeiller, Discopteris vuellersii Stur, Sphenopteris (Boweria) schatzlarensis (Kidston) Jongmans, Sphenopteris (Zeilleria) delicatula Sternberg and Sphenopteris (Zeilleria) haidingerii Ettingshausen. Pennsylvanian leptosporangiate ferns acquired a variety of growth habits and occupied a wide range of ecological habitats (DiMichele \& Phillips, 2002).
Tedeleaceae ferns having Ankyropteris-type of anatomy (Phillips \& Galtier, 2011) in the studied horizons are represented by the compression genus Senftenbergia (Jennings \& Eggert, 1977), which had a vine/climbing habit (Rössler, 2000; Phillips \& Galtier, 2011). Remains of this genus are often found in association with zygopterid ferns as observed not only in the horizons studied but also in some coals of the Illinois Basin (Phillips \& Galtier, 2005) and in the Union Seam (England) (Holmes \& FaironDemaret, 1984). All these observations are consistent with the presumed ecological preferences of Zygopterid 


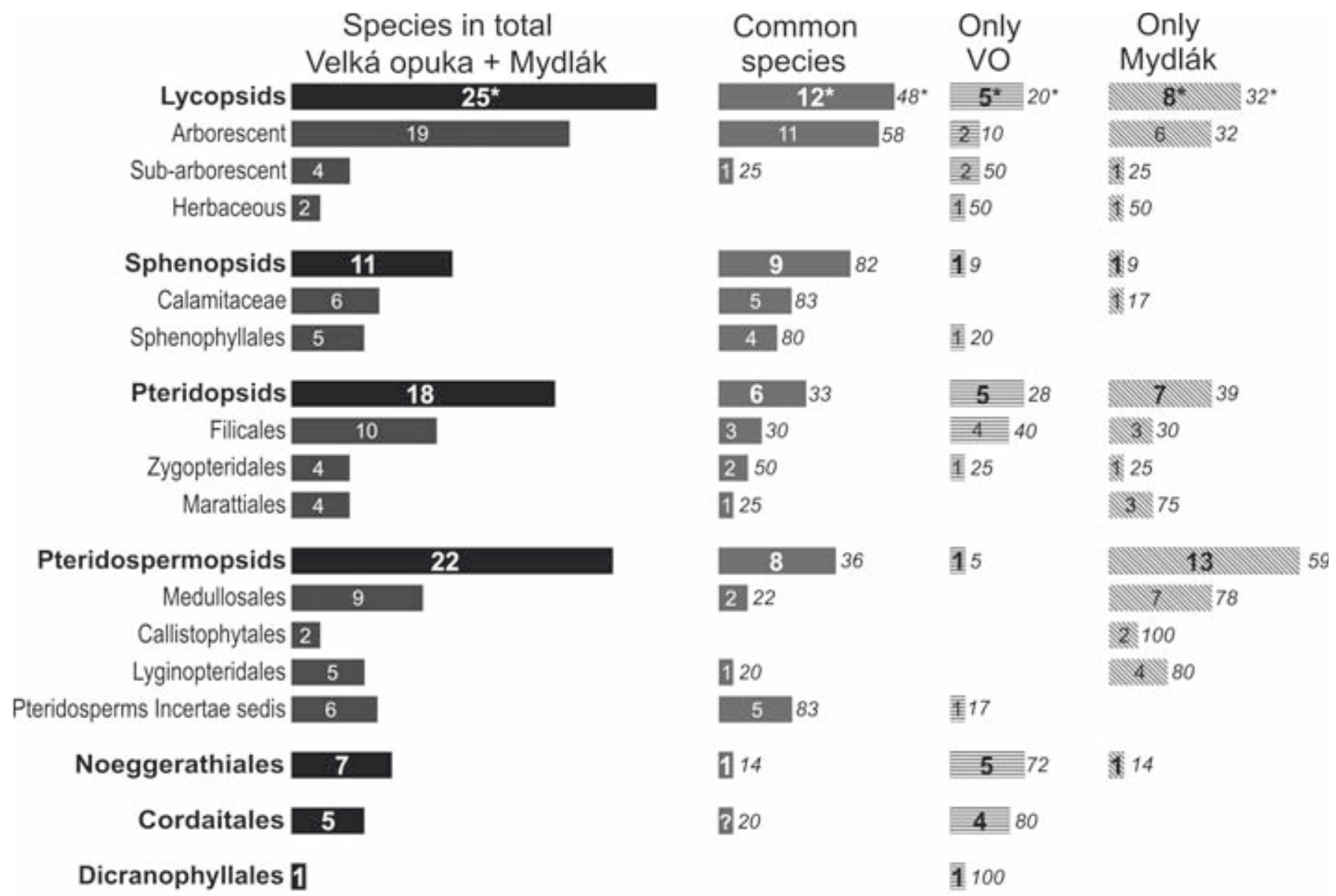

- Numbers in boxes refer to number of species, numbers in italics indicate percentage

Figure 9. Fossil plant diversity of the Velká opuka and Mydlák according to their systematic position. Species common to both horizons are indicated, as are those unique to only one of them.

ferns in disturbed, water-stressed environments with (?) fluctuating water table and/or exposed substrates (Phillips $\&$ Galtier, 2005). Senftenbergia is also a common part of plant associations in the Mydlák as derived from marginal areas, where exposed substrates do not occur.

Ferns of Sermayaceae have an Anachoropteris-type anatomy and Oligocarpia-type reproductive organs (Eggert \& Delevoryas, 1967). Most species with Anachoropteristype of anatomy come from non-coal swamp environments (Galtier \& Phillips, 2014), except for some species preserved in a tuff bed in the roof of the Lower Radnice Coal (Corda, 1845), which colonized peat-forming habitats. Generally Anachoropteris foliar remains were borne on Tubicaulis-type stems (Phillips, 1974; Galtier \& Phillips, 2014) having semi-erect to erect habitus. DiMichele \& Phillips (2002) suggested that they are "walking ferns", which produced stem buds on scrambling frond rachides enabling them to spread rapidly across the substrate. Another type with Anachoropteris anatomy shows a scrambling or climbing adaptation (Corsin, 1937; Galtier, 2008). This adaptation can be seen in Oligocarpia lindsaeoides with recurved penultimate pinna rachides arching over the adaxial side of the main rachis. This species is more or less common in the Velká opuka.

Our knowledge of the last group of filicaleaen ferns placed into Incertae sedis (Fig. 6) is very limited because only reproductive organs are known. They suggest affinities to Anachoropteris, Psalixochlaena, Tubicaulis, Ankyropteris or Sermaya. Nevertheless, without relevant data on anatomy of the rachides, it is impossible to determine their ecological role in the assemblage.

\subsection{Pteridospermopsida}

Medullosan pteridosperms are uncommon in the Velká opuka and common in the Mydlák in the Kladno Coalfield (Figs 6, 16, 17). The most common medullosalean species are those assigned formerly to Neuropteris (Brongniart) Sternberg. However, cuticular studies have allowed their classification into several genera (Cleal \& Shute, 1995; Šimůnek \& Cleal, 2011). Laveineopteris loshii 


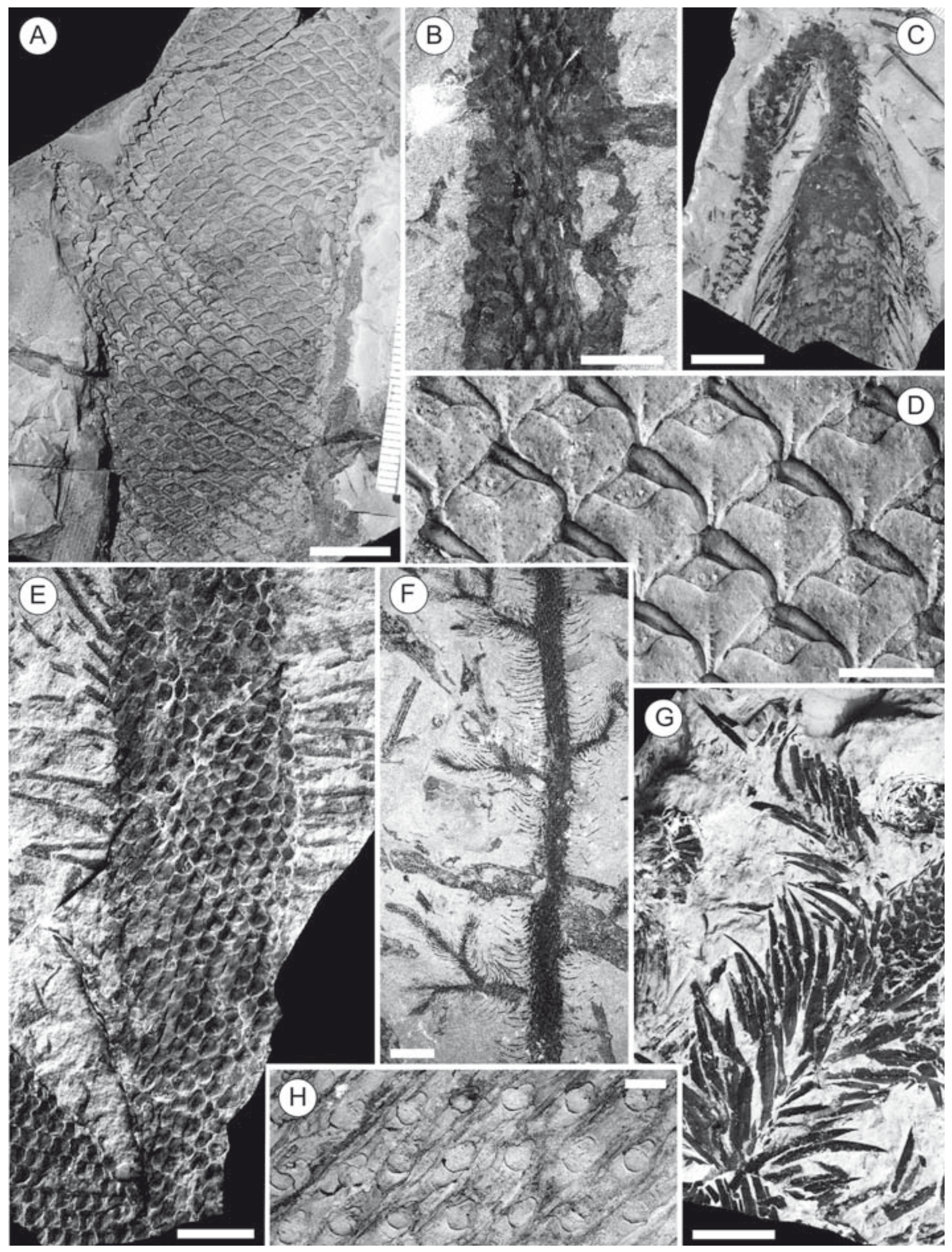


(Brongniart) Cleal, Shute \& Zodrow is abundant in the "Bělka", a volcanic band in roof of the Lower Radnice Coal, but only occurs sporadically in the Velká opuka and Mydlák. Laveineopteris tenuifolia (Sternberg) Cleal, Shute \& Zodrow and L. bohemica (formerly identified as Neuropteris attenuata by Havlena, 1953), are relatively abundant in the Mydlák. This is also the case of isolated pinnules of Paripteris linguaefolia (Bertrand) Laveine. In contrast, Macroneuropteris scheuchzeri (Hoffmann) Cleal, Shute \& Zodrow is less common in the Mydlák. Linopterids are represented by a single species, Linopteris neuropteroides Gutbier forma major Potonié. Its detached pinnules occur in places in the Mydlák and sporadically also in the Velká opuka.

Alethopterids are represented only by Alethopteris distantinervosa Wagner and A. cf. serlii (Brongniart) Goeppert, which both occur in the Mydlák. A. distantinervosa, originally described as Alethopteris grandini (Brongniart) by Němejc (1936), is more common, whereas Alethopteris cf. serlii is represented by only a few specimens (Fig. 17G). Wagner (1968) distinguished two quite similar species Alethopteris distantinervosa and Alethopteris grandinioides Kessler in Central Bohemia. However, Šimůnek (1989) considered these species as varieties of Alethopteris grandinioides Kessler because of the strong similarity of their cuticles. Since Alethopteris grandinioides is typical for late Bolsovian and Asturian in western Europe, Šimůnek \& Cleal (2002) again revised specimens of these two species and came to the conclusion that there is only one species with wide pinnule variability and that the correct name is Alethopteris distantinervosa. The species Alethopteris cf. serlii has been described by Němejc (1936) and by Wagner (1968) as Alethopteris serlii. However, Cleal (pers. com.) claims that true Alethopteris serlii is known only from Great Britain and North America, so we describe it here as Alethopteris cf. serlii because of its strong similarity.

"Mariopterids" are represented by Mariopteris muricata (Schlotheim) Zeiller and Fortopteris radnicensis (Němejc) Boersma. Both species are relatively rare in the Radnice coal group and occur only in Mydlák. Much more common are representatives of the order Lyginopteridales, particularly the genus Eusphenopteris Simson-Sharold. The following species occur in the Radnice group of coals: Eusphenopteris nummularia (Gutbier) Novik, E. obtusiloba (Brongniart) Novik, E. neuropteroides (Boulay) Novik, E. sauveurii (Crépin) Simson-Sharold and E. schumannii (Stur) van Amerom. Nearly all these species have been found only in the Mydlák, except for $E$. nummularia, which also occurs rarely in the Velká opuka. E. nummularia and E. obtusiloba belong to the most common species in the Mydlák. The species E. sauveurii is also relatively common but $E$. neuropteroides and $E$. schumannii are very rare.

There are several species of uncertain affinity assigned mostly to the genus Sphenopteris (Brongniart) Sternberg except Palmatopteris furcata (Brongniart) Potonié. Pinnules of these species are of sphenopterid type and fructifications are usually unknown. Palmatopteris furcata is common in the Mydlák and Velká opuka. Fairly abundant in the Mydlák are Sphenopteris (Palmatopteris) spiniformis Kidston and $S$. mixta Schimper whereas $S$. spinosa Goeppert is quite rare here. Most common in the Velká opuka are S. pulchrior Gothan \& Jongmans (also Eusphenopteris - van Amerom, 1975) and especially S. flexuosissima Stur, the latter originally identified as the fern Sphenopteris cf. crepinii (Opluštil et al., 2007). In this study we re-interpreted this species as Sphenopteris flexuosissima and assigned it within pteridosperms. The reason is the presence of Lyginopterid-type of pollen organs (Fig. 16D) similar to those of Crossotheca kentuckiensis (Stubblefield et al., 1982). In situ miospores (unpublished data) are monolete, showing an affinity to pollens rather than to spores.

The most "exotic", very sporadic species is Havlenaea praeovata (Němejc) Šimůnek \& Cleal, found in the Kladno Coalfield only by a few fragments in the Mydlák and probably representing a species drifted in from habitats situated higher elevations, possibly from basement palaeohighs in the surroundings of the valley.

Figure 10. Examples of lycopsids identified from the Velká opuka. A) Lepidodendron longifolium Presl in Sternberg. Theodor Mine, J. Haldovský collection; scale bar $10 \mathrm{~mm}$. B) Spencerites chalonerii Drábková et al. Holotype. Prago Mine, National Museum collection, Prague (E 3684); scale bar $10 \mathrm{~mm}$. C) Lepidostrobus cernuus (Sternberg) Němejc. A Cappasporitesbearing cone attached to the shoot of Lepidodendron longifolium. Ronna Mine, National Museum in Prague; scale bar $20 \mathrm{~mm}$. D) Lepidodendron longifolium Presl in Sternberg. Detail of leaf cushions of a branch. Mayrau Mine, S. Opluštil collection; scale bar $5 \mathrm{~mm}$. E) Omphalophloios feistmantelii (Feistmantel) Bek et al. Ronna Mine, National Museum in Prague (E973); scale bar 20 mm. Previously figured in Opluštil et al. (2007, pl. VII, fig. 6) F) Lepidodendron ophiurus sensu Němejc (non Brongniart). Leafy shoot from the Ronna Mine. Same as Opluštil et al. (2007, pl. VII, fig. 1). West Bohemian Museum in Pilsen; scale bar $10 \mathrm{~mm}$. G) Bergeria dilatata (Lindley \& Hutton) Álvarez-Vázquez \& Wagner. Leafy shoot. Kladno, National Museum in Prague; scale bar $20 \mathrm{~mm}$. H) Sigillaria pachyderma Brongniart. Schoeller Mine, S. Opluštil collection; scale bar $20 \mathrm{~mm}$. 


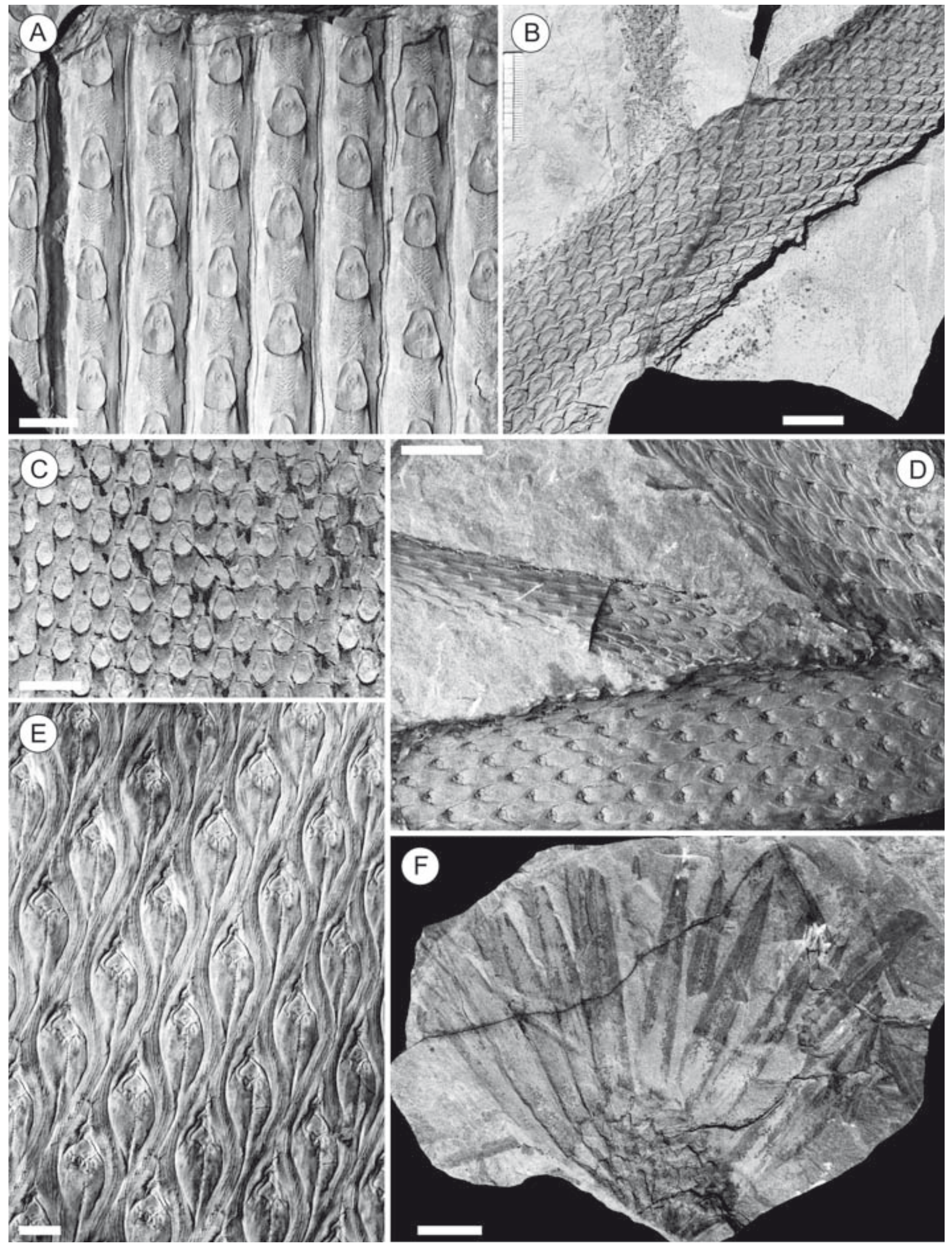




\subsection{Noeggerathiales}

The members of this group of plants are relatively rare at both horizons (Figs 6, 18). They are represented by two families: Noeggerathiaceae and Discinitaceae. Noeggerathiaceae comprise two species Noeggerathia foliosa Sternberg and $N$. intermedia Feistmantel (Šimůnek \& Bek, 2003). N. foliosa occurs rarely in both fossilbearing horizons (but seems to be more common in the "Velká opuka"), whereas $N$. intermedia has been found so far only in the "Velká opuka". According to Šimůnek \& Bek (2003) these plants were about 1-1.5 m tall "trees", which may be considered as an adaption to habitats with unstable soft substrate, e.g., peat.

The family Discinitaceae is represented by two genera, Rhacopteris Schimper and Palaeopteridium Kidston (Fig. 6). Their common character is that they produced Discinites Feistmantel cones (Bek \& Šimůnek, 2005). Rhacopteris (Rhacopteris elegans (Ettingshausen) Schimper, $R$. bipinnata Němejc and $R$. speciosa Ettingshausen) was found only in the Velká opuka. Palaeopteridium is represented by $P$. macrophyllum Němejc in the Velká opuka, and by $P$. reussii Ettingshausen in the Mydlák (Fig. 6). That Rhacopteris belonged to the family Discinitaceae was demonstrated by Němejc (1941), who found a fragment of discinite-type cone attached to Rhacopteris bipinnata rachis.

Absence of information on the anatomy of these plants limits speculation on their ecological role in phytocoenoses.

\subsection{Cordaitanthales}

During the $19^{\text {th }}$ and the $20^{\text {th }}$ century only few cordaitalean species were identified in the Kladno-Rakovník Basin including the Kladno Coalfield (Figs 6, 18). Their specific determination was based solely on venation pattern (e.g., Feistmantel, 1874). However, the modern cuticular studies by Šimůnek (2007) and Šimůnek \& Haldovský (2015), revealed the higher diversity of this plant group than previously suspected. Four Cordaitalean species were distinguished in the Velká opuka; unfortunately, no sample from Mydlák was macerated (Fig. 6). All species possess lanceolate leaves, except the very rare Cordaites latus Šimůnek, which has clavate leaves. The species C. kladnoensis Šimůnek and C. wartmannii Šimůnek are relatively common. Cordaites theodorii Šimůnek \& Haldovský, on the other hand, occurs only sporadically and is the only cordaitalean species with a dentate leaf margin; it is further characteristic by densely papillated epidermal cells, a morphological feature typical of peatforming cordaitaleans (Šimůnek \& Florjan, 2013).

\subsection{Dicranophyllales}

When listing plant species found in the Velká opuka, we must not forget to Dicranophyllum dominii Němejc, 1929, which was described originally from this bed (Fig. 6). This short-leaved form is relatively rare in the Velká opuka. The systematic position of dicranophylls remains problematic, but most authors prefer to place them with the conifers (Barthel \& Noll, 1999; Taylor et al., 2009).

\section{ASSEMBLAGES OF THE VELKÁ OPUKA AND MYDLÁK}

Analyses performed on the data presented in Figures 6 and 7 and further expressed in Figures 8, 9 and 19 suggest differences in composition and diversity of vegetation that colonized the Kladno coalfield during the deposition of the Velká opuka and the Mydlák. In addition, differences also were observed in the frequency of occurrence of taxa common to the two horizons.

\subsection{Velká opuka}

A simple reading of the data in Figure 6 suggests that the flora of the Velká opuka (VO) is less diverse than that of the Mydlák, and is dominated by lycopsids, calamitaleans and some ferns; pteridosperms occupy a subordinate position. Although this is generally true, a more detailed analysis shows that two contrasting plant assemblages may be recognised in the Velká opuka based on detailed studies of the macroflora (Opluštil et al., 2007) and palynoflora (Opluštil et al., 1999). The first assemblage is dominated by sub-arborescent lycopsid Omphalophloios feistmantelii which is very typical of the Velká opuka (Bek et al., 2015). In the second

Figure 11. Lycopsids from the Mydlák. A) Sigillaria pachyderma Brongniart. Theodor Mine, J. Haldovský collection; scale bar 10 mm. B) Lepidodendron mannebachense Presl in Sternberg. Theodor Mine, J. Haldovský collection; scale bar 20 mm. C) Sigillaria trigona Sternberg. Ronna Mine, Faculty of Sciences collection, Charles University in Prague; scale bar $10 \mathrm{~mm}$. D) Bergeria dilatata (Lindley \& Hutton) Álvarez-Vázquez \& Wagner. Kladno Coalfield, precise mine unknown. National Museum in Prague (E1914), scale bar $20 \mathrm{~mm}$. E) Lepidodendron aculeatum Sternberg. Kladno Coalfield, precise mine unknown. National Museum in Prague; scale bar $10 \mathrm{~mm}$. F) Lepidostrobophyllum majus (Brongniart) Hirmer. Part of a cone. Theodor Mine, J. Haldovský collection; scale bar $20 \mathrm{~mm}$. 


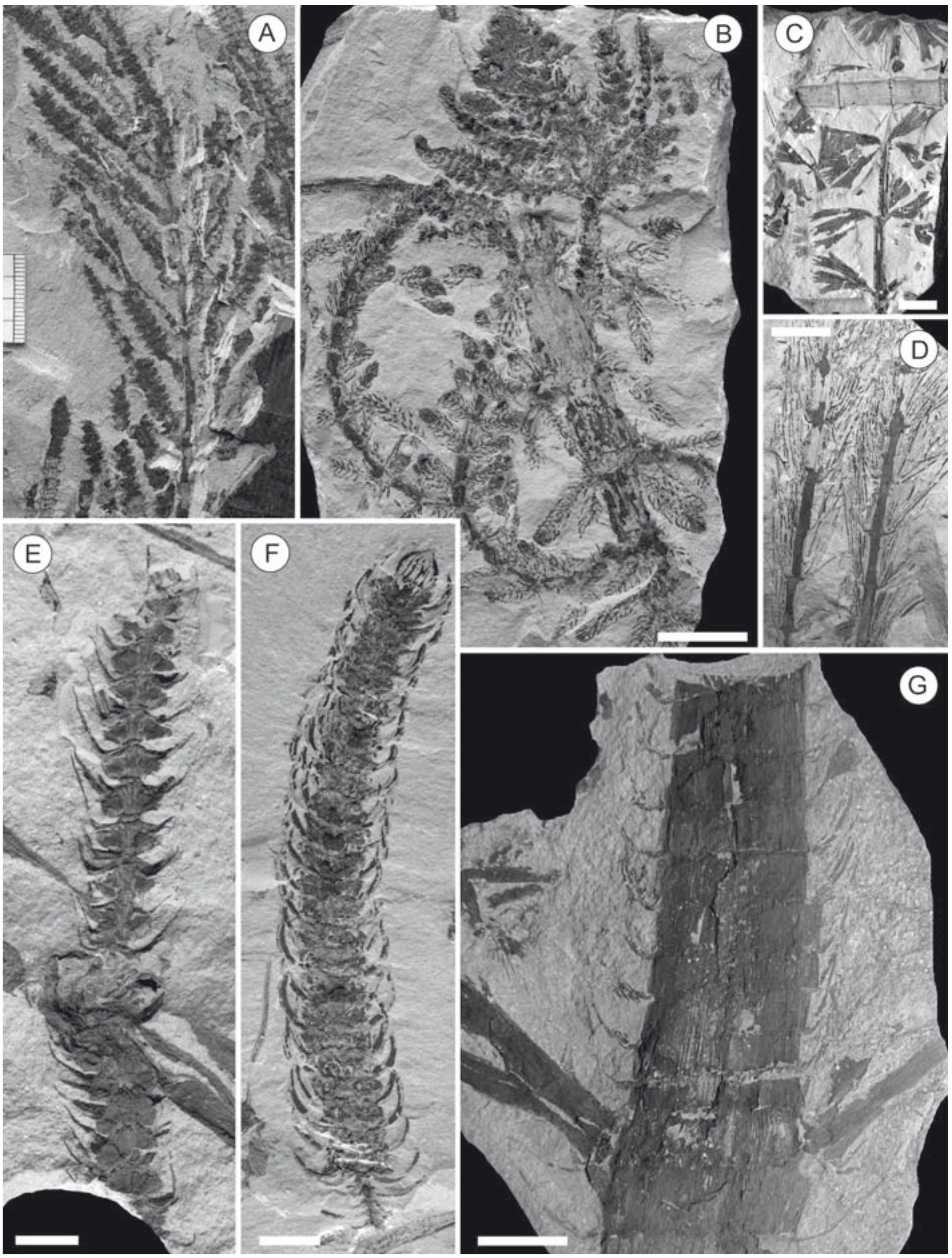


assemblage lepidodendrid lycopsids bearing lycospores and Cappasporites are predominant. Common to abundant are Lepidodendron longifolium and L. ophiurus, both typical of the Velká opuka. Fairly common in the Velká opuka are also Lepidodendron simile and Lepidophloios laricinus. Both assemblages in the Velká opuka are accompanied by abundant calamitaleans; especially common are the foliage Asterophyllites grandis and A. longifolius foliage, and the strobili Palaeostachya ettingshausenii, P. gracillima, P. distachya, P. elongata and Calamostachys grandis. Common are also sphenophylls including Sphenophyllum pseudoaquense, typical of the Velká opuka, S. priveticense, S. taylorii and S. cuneifolium. Ferns of the Upper Radnice Coal preserved in the Velká opuka mostly belong to Corynepteris sternbergii (zygopterid) with subdominant Desmopteris longifolia (zygopterid), Senftenbergia plumosa (ankyropterid anatomy), Oligocarpia lindsaeoides and the marattialean fern Lobatopteris aspidioides. The autochtonous co-occurrence of ankyropterids and zygopterids highlights a water-stressed environment (Phillips \& Galtier, 2005). Pteridosperms are generally rare, except Sphenopteris flexuossisima (=S. crépinii?) and $S$. pulchrior, which are fairly abundant.

\subsection{Mydlák}

Plant associations found in the Mydlák vary from place to place but are generally dominated by Calamites. Most common are pit casts of Calamites undulatus and C. suckowii with subordinate $C$. goeppertii. These are associated with the strobili Palaeostachya ettingshausenii, P. pedunculata and Calamostachys grandis.

Calamitalean foliage typical for the Mydlák includes Annularia radiata and Asterophyllites grandis (also abundant in the VO), A. equisetiformis, A. longifolius; typical only for the Mydlák is A. charaeformis. Sphenophylls are also abundant; the most common is Sphenophyllum myriophyllum, characteristic of the Mydlák, also with $S$. priveticense and $S$. cuneifolium (common also in the VO).

Pteridosperm are among the most common remains found in the Mydlák. Of about 21 species of this group identified at this horizon, Laveineopteris bohemica and/ or L. tenuifolia are most abundant. Paripteris linguaefolia has a subordinate presence. Elsewhere, similarly abundant is the association of Eusphenopteris nummularia together with Sphenopteris spiniformis, whereas Palmatopteris furcata and E. obtusiloba are less common.

Lycopsids are locally frequent, typically represented by Lepidodendron aculeatum and L. mannebachense (L. obovatum), which are rare or absent in the VO. Also common are Bergeria dilatata and Lepidophloios laricinus but these also occur in the VO.

Ferns are relatively less common in the Mydlák than in the Velká opuka, except for abundant Senftenbergia plumosa and Lobatopteris aspidioides. Locally common are also Sphenopteris schatzlarensis and S. delicatula, both belonging to the Filicales.

Locally common are also cordaitaleans, however, their diversity is based only on the venation pattern, and thus is not comparable with cuticular study-based diversity of this group in the VO.

\section{COMPARISONS}

The list of taxa provided in Figure 6 and its graphic expression (Figs 8,9) show differences between floras of the VO and the Mydlák. These differences do not only refer to species composition but also the abundance of some taxa. The Mydlák flora is also characterized by twice the higher diversity, and also a greater abundance of pteridosperms compared to the VO. A higher diversity, although less striking, also exists with regard to the arborescent lycopsids and pteropsids. On the other hand, only minor differences in the number of species were found for the sphenopsids.

Field collecting of fossils in the VO and Mydlák during several last decades shows that both horizons are very rich in remains of sphenopsids and arborescent lycopsids. However, differences may exist in the abundance of common species and the presence/absence of species unique for only one of the horizons. Striking examples are the abundance of Lepidodendron aculeatum and $L$. mannebachense in the Mydlák, whereas these are absent or very rare in the VO. On the other hand, L. ophiurus and L. longifolium are abundant in the VO but nearly absent in the Mydlák.

Although diversity of pteridosperms in the Mydlák is high, only 8 species are really abundant. The most

Figure 12. Sphenopsids from the Velká opuka. A) Palaeostachya gracillima Weiss. Kladno Coalfield, precise mine unknown. National Museum in Prague. B) Asterophyllites grandis (Sternberg) Geinitz. Kladno Coalfield, precise mine unknown. National Museum in Prague; scale bar 20 mm. C) Sphenophyllum priveticense Libertín et al. Theodor Mine, J. Haldovský collection; scale bar $10 \mathrm{~mm}$. D) Asterophyllites longifolius (Sternberg) Brongniart. Ronna Mine, Sládeček Museum in Kladno; scale bar 20 mm. E) Palaeostachya ettingshausenii Kidston. Kladno Coalfield. National Museum in Prague; scale bar $5 \mathrm{~mm}$. F) Calamostachys grandis (Zeiller) Jongmans. Kladno Coalfield. National Museum in Prague; scale bar 5 mm. G) Calamites (Calamitina) goeppertii (Ettingshausen) Weiss. Kladno Coalfield, Sládeček Museum in Kladno; scale bar 20 mm. 

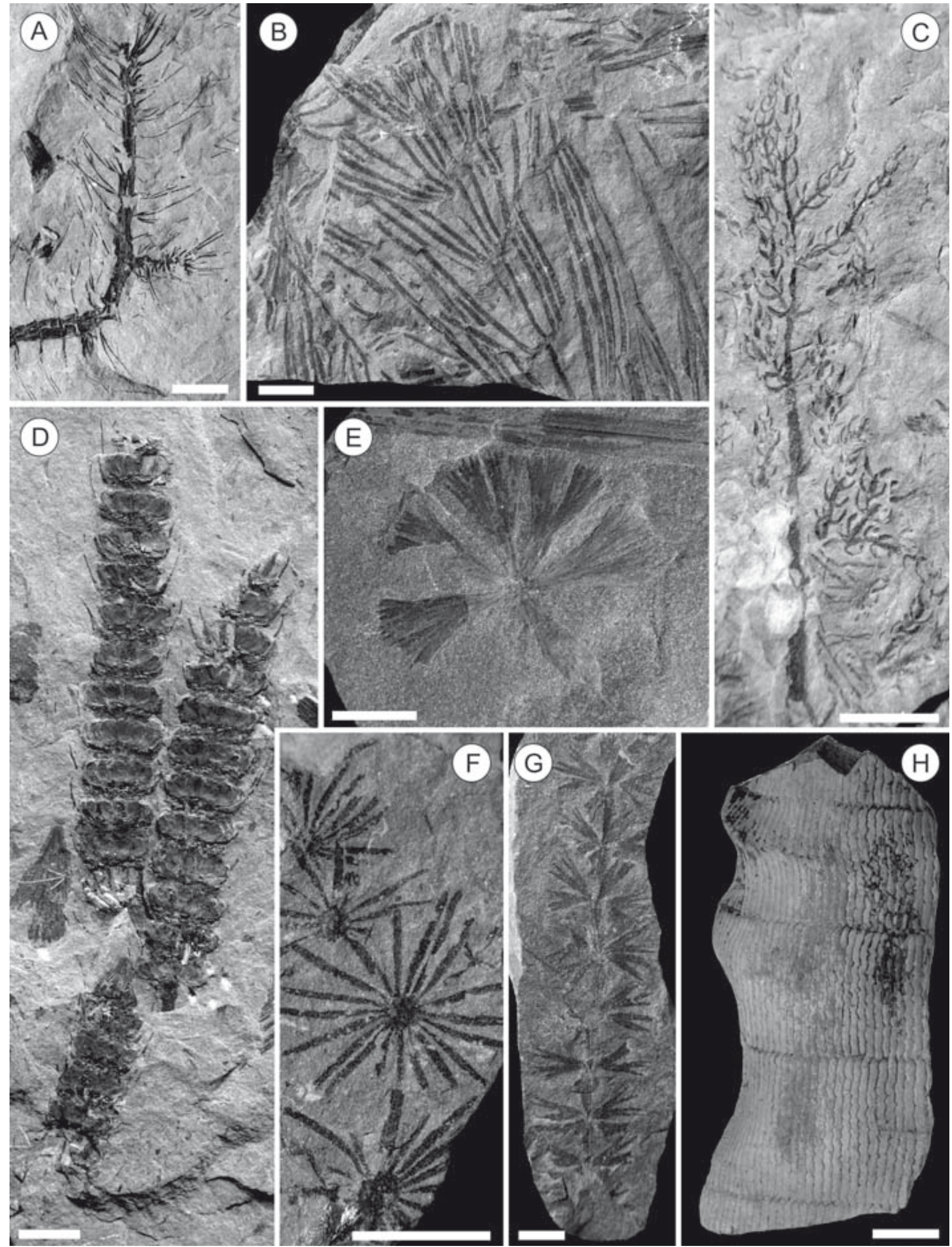
important ones are: Laveineopteris bohemica, L. tenuifolia, Eusphenopteris nummularia, Sphenopteris spiniformis and Palmatopteris furcata. Other taxa are subordinate or rare, as in the case of the genus Alethopteris. Other species which are very abundant in only one of the horizons, and thus characterize it, include Sphenophyllum myriophyllum for the Mydlák, whereas Corynepteris sternbergii and Omphalophloios feistmantelii are characteristic of the VO. These are the most salient examples, but, of course, there are additional species that characterize one or the other horizon. However, these are not abundant (e.g., Spencerites chalonerii, Dicranophyllum dominii in the VO).

Comparison can be made with taphonomically similar floras elsewhere. The peat-forming flora of the VO can be best compared with that of the Bělka tuff bed (Opluštil et al. 2009a, b, 2014) and from coal balls (Phillips et al., 1985). The Bělka is an about half a metre thick volcanic ash bed in the roof of the Lower Radnice Coal and situated just below the Upper Radnice Coal, being of comparable age and palaeogeographic position. Excavations made in the Radnice Basin $60 \mathrm{~km} \mathrm{SW}$ of the Kladno Coalfield exposed an in situ preserved lepidodendrid - cordaitalean-dominated forest association with abundant calamitaleans in the understory and a dense herbaceous groundcover. Although the lepidodendrid species are partly different from those in the VO, a common feature of both volcaniclastic beds is the absence of Lepidodendron aculeatum and only rare occurrences of $L$. mannebachense, as well as a dominant presence of certain taxa (e.g., L. lycopodioides), which are found sporadically in clastic sediments accompanying the Lower Radnice Coal. Similarly for the Berlka and VO the filicalean fern Senftenbergia plumosa and of zygopterid fern Corynepteris (C. angustissima in the Bělka) occur abundantly. Apart of the VO, however, the Bělka forest shows a higher abundance of medullosalean pteridosperms as represented by Laveineopteris loshii which is nearly absent in the VO. Fairly abundant pteridosperms include also Eusphenopteris nummularia, Mariopteris muricata and Palmatopteris furcata, which are characteristic of the Mydlák. Only the remains of Sphenopteris mixta are common in both beds; this is a species very similar to $S$. flexuosissima, which is very abundant in the VO. A relative abundance of pteridosperms in the Berlka thus matches the flora of the Mydlák more than that of the VO.
Besides the peat-forming vegetation preserved in tuff beds, the VO flora may also be compared with coal ball floras as studied by Phillips et al. (1985). These authors show that late Duckmantian peats were composed of nearly 70 vol. \% of lycopsids, mostly of the arborescent type, whereas the other plant groups only represent $\leq 10 \%$ of peat volume. Although these frequency values are not directly comparable with our data from the $\mathrm{VO}$, which are only semi-quantitative, they both demonstrate the important role played by arborescent (mostly lepidodendrid) lycopsids in the peat-forming vegetation of those times. However, appart from the pteridosperms, the VO flora shows more important role of sphenopsids, with particular regard to the calamitaleans in the peat swamp of the Upper Radnice Coal. This difference may be, however, of taphonomic nature. Analysis of coal-ball peat showed that calamitaleans are often preferentially abundant in highly degraded peats, where they are often represented mainly by rhizomes and roots (the aerial debris having decayed). Thus they may be "under-represented" in many coal ball floras, if they were growing in areas where peat decay was common (W.A. DiMichele, pers. comm.).

The Mydlák can be compared with roof shale floras of similar age elsewhere. For instance, a Langsettian fossil forest preserved in the roof-shales of the Blue Creek Coal in the Mary Lee Coal zone of the Black Warrior Basin, Alabama (Gastaldo et al., 2004) is dominated by arborescent lycopsids of the genera Lepidodendron, Lepidophloios and Sigillaria with abundant undergrowth consisting of calamitaleans, pteridosperms (Lyginopteris, Alethopteris, Neuralethopteris) and a ground cover or lianas as represented by Eusphenopteris and Palmatopteris. Despite the stratigraphically older position of this flora, the abundance of pteridosperms and calamitaleans within a lepidodendrid forest of varying density is similar to that of the Mydlák. In contrast, an early Asturian plant assemblage from roof shale of Secor Coal in Oklahoma (DiMichele et al., 1991) is dominated by medullosan pteridosperms, with subdominant marattialen ferns and calamiteans, whereas arborescent lycopsids are quite rare and represented by sigillarians. Although this forest differs from that of the deposits described herein, in the subordinate role of arborescent lycopsids, a dominant presence of pteridosperms (together with calamitaleans and

Figure 13. Sphenopsids from the Mydlák. A) Sphenophyllum myriophyllum Crépin. Tuchlovice Mine, S. Opluštil collection; scale bar $20 \mathrm{~mm}$. B) Asterophyllites cf. longifolius (Sternberg) Brongniart. Theodor Mine, collection of S. Opluštil; scale bar $10 \mathrm{~mm}$. C) Asterophyllites charaeformis (Sternberg) Goeppert. Barré Mine, S. Opluštil collection; scale bar $10 \mathrm{~mm}$. D) Palaeostachya ettingshausenii Kidston. Tuchlovice Mine, S. Opluštil collection; scale bar 5 mm. Figured by Bek \& Opluštil (1998, pl. 3, fig. 12). E) Sphenophyllum priveticense Libertín et al. Tuchlovice Mine, S. Opluštil collection; scale bar $10 \mathrm{~mm}$. F) Annularia radiata (Brongniart) Sternberg. Schoeller Mine, S. Opluštil collection; scale bar $10 \mathrm{~mm}$. G) Sphenophyllum taylorii. Tuchlovice Mine, S. Opluštil collection; scale bar $5 \mathrm{~mm}$. H) Calamites (Stylocalamites) undulatus Sternberg. Max Mine, S. Opluštil collection; scale bar $20 \mathrm{~mm}$. 

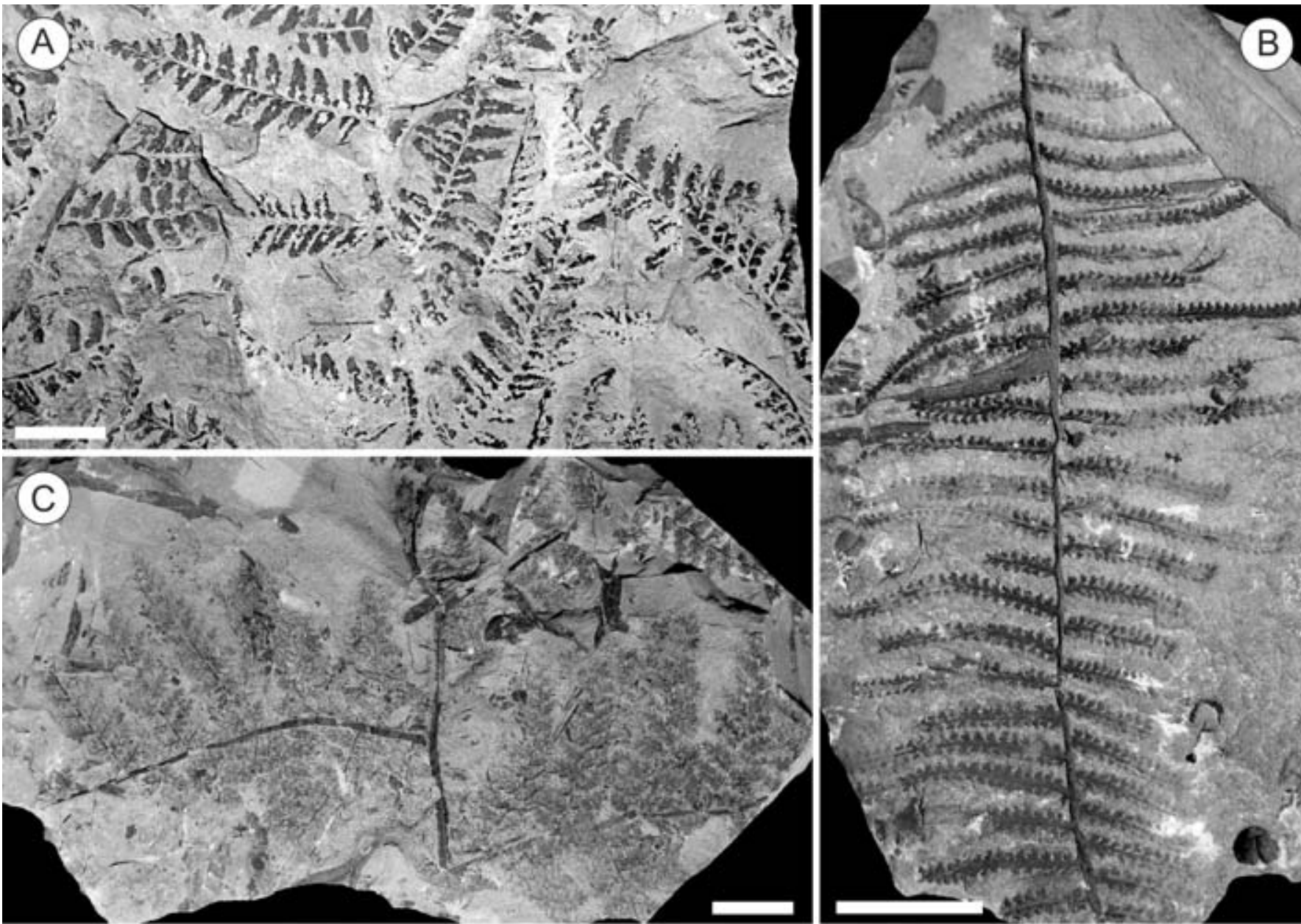

(D)

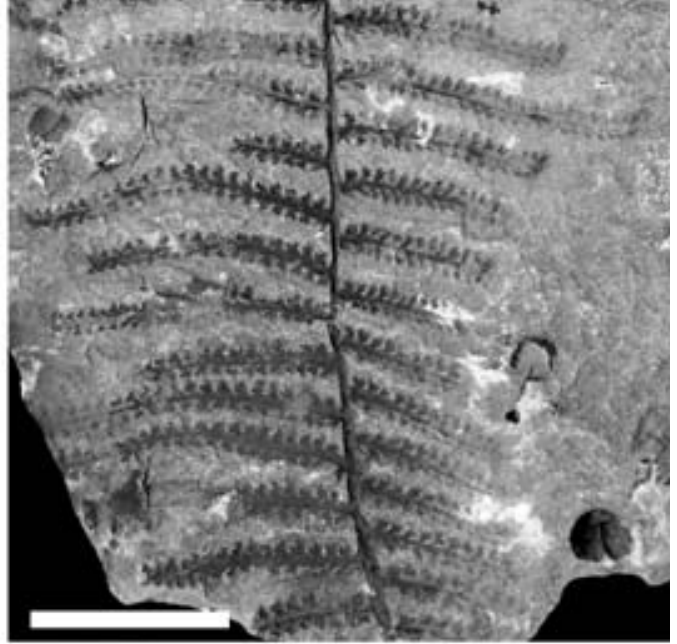

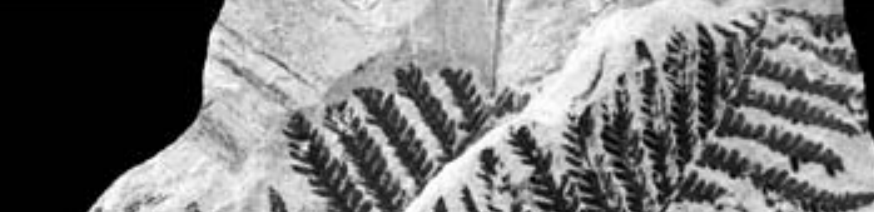
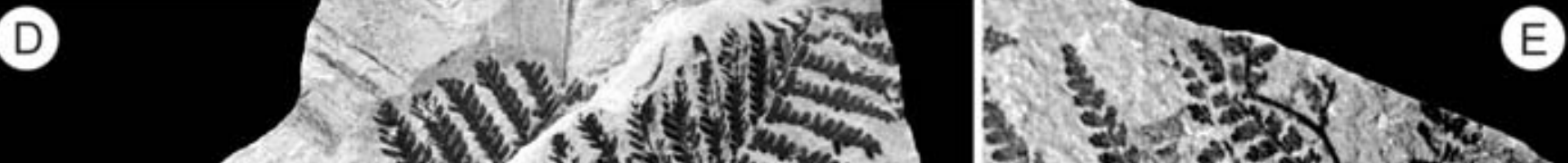

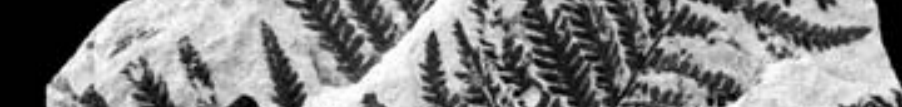

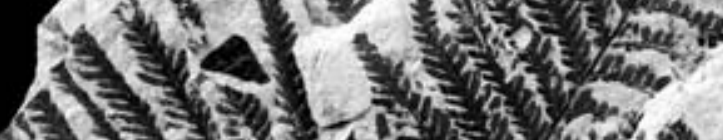

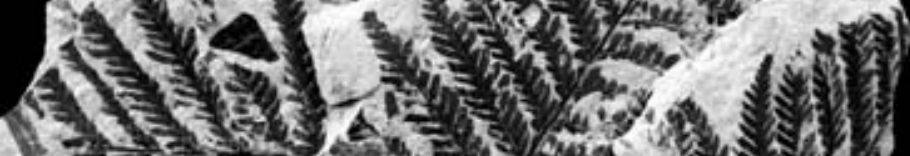

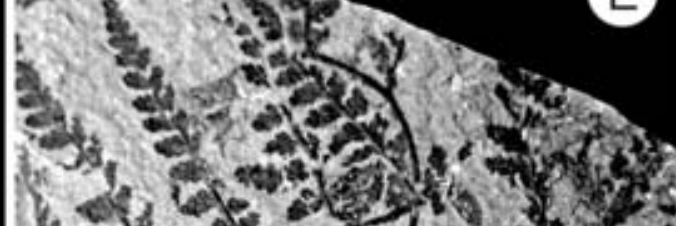
21.

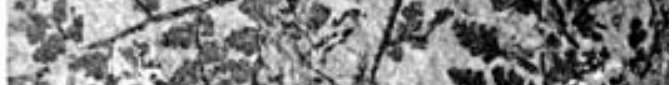

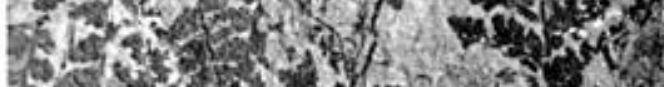

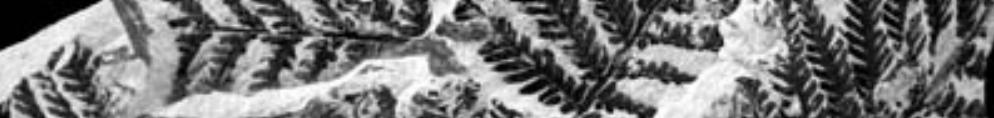
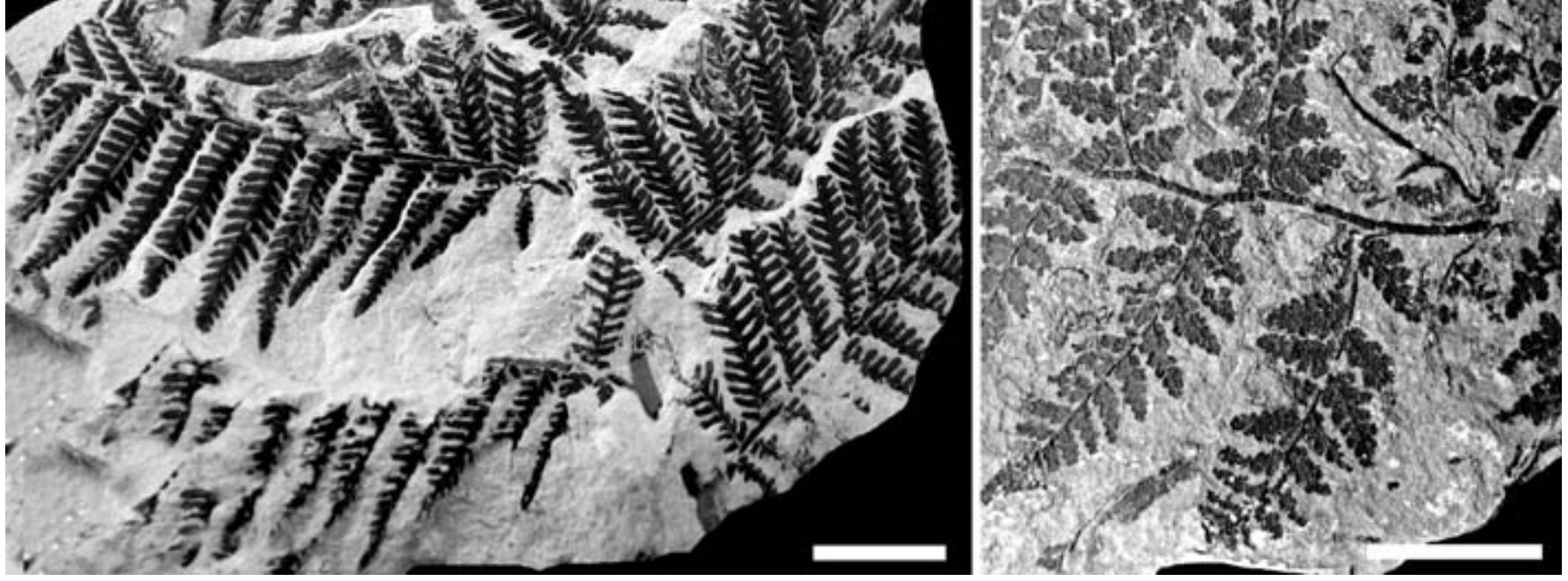
tree ferns) is similar to that of the Mydlák and seems to be a typical feature of mineral-rich wetlands (Gastaldo, 1987). Our data thus confirms that pteridosperms had a stronger preference for mineral-enriched wetlands that immediately followed upon the development of peat swamps.

\section{SUMMARY AND CONCLUSIONS}

1) The Upper Radnice Coal (late Duckmantian) is the principal seam of the Kladno Coalfield in the southern sector of the Kladno-Rakovník Basin. Its formation was controlled by palaeotopographic features. The peat swamp which developed into the coal covered nearly the entire width of a palaeovalley and was surrounded by basement palaeohighs.

2) Intercalated in the lower part of the coal is a $\sim 10$ $\mathrm{cm}$ thick volcaniclastic bed called Velká opuka, which contains a flora buried in situ by volcanic ash. The coal is capped by laminated roof shales (Mydlák), carrying parautochthonous to mostly allochthonous coalified plant compressions transported over short distances, less than $2 \mathrm{~km}$.

3) Floras of both these fossiliferous horizons comprise the same families and genera, but differ in their proportions (abundance) and, largely, in species composition.

4) Differences in the composition of both floras with respect to their taphonomy suggest that the plant fossils in the Velká opuka represent the peat-forming vegetation growing on an organic substrate, whereas plant remains in the Mydlák are mostly derived from the vegetation occupying mineral-rich coastal wetlands, which were established after the peat swamp withdrew.

5 ) About 59 biological plant species have been identified from the Velká opuka and 67 species from the Mydlák. In all, 89 biological taxa have been identified in both fossiliferous horizons. This number includes 37 species which they have in common; 22 species are found only in the VO and 30 species have been identified so far only from the Mydlák.

6) The flora of the VO is dominated by lycopsids, either by arborescent lepidodendrids with subordinate sigillarians or by the subarborescent genus Omphalophloios. Codominant are the sphenopsids, calamitaleans as well as sphenophylls, whereas ferns and cordaitaleans are locally common. Pteridosperms, especially medullosaleans, are rare and less diverse in VO as compared with the Mydlák.

7) The Mydlák flora is more diverse and differs from that of the Velká opuka by a significantly higher diversity and the abundance of pteridosperms, including medullosaleans. Lycopsids are less abundant, especially the lepidodenderids.

8) The VO and Mydlák floras are further characterized by some taxa, which are only dominant in one of these fossiliferous beds. Characteristic of the Velká opuka are the abundant remains of Omphalophloios feistmantelii, Lepidodendron longifolium and L. ophiurus (sensu Němejc, 1947). Dominant in the Mydlák are remains of Laveineopteris tenuifolia, L. bohemica, Sphenopteris spiniformis, Eusphenopteris nummularia, Lepidodendron aculeatum and L. mannebachense.

9) Our data thus support earlier observations suggesting that the clastic wetlands floras tend to be dominated by pteridosperms, sphenopsids and ferns, with subdominant lycopsids.

\section{ACKNOWLEDGEMENTS}

We are very pleased to have the opportunity to contribute to the volume in honour of Robert H. Wagner, an excellent palaeobotanist and our friend, who dedicated his life to the Carboniferous palaeobotany. The authors are very grateful to William DiMichele and John Knight for their careful revision of the manuscript and useful suggestions, which improved the paper significantly. These authors are also thanked for language revision of the text. Our thanks belong also to Carmen Álvarez-Vázquez for her effort, when handling the submitted manuscript during revision process. The authors greatly appreciate the cooperation with Jan Haldovský, an amateur collector from Pchery near Kladno, who made his extensive collection of plant fossils from the Kladno Coalfield available for examination. Thanks are given to the National Museum in Prague and to the Sládeček Museum in Kladno for access to their plant fossil collections. This paper benefited from a support via the project P210-12-2053 of the Grant Agency of the Czech Republic. Mr. Josef Seifert is thanked for providing a photo in the Figure 4B.

Figure 14. Ferns from the Velká opuka. A) Senftenbergia cf. pennaeformis (Brongniart) Stur. Kladno Coalfield, Sládeček Museum in Kladno; scale bar 20 mm. B) Corynepteris sternbergii. Kladno Coalfield, Sládeček Museum in Kladno; scale bar 20 mm. C) Oligocarpia gutbieri Goeppert. Kladno Coalfield, Sládeček Museum in Kladno; scale bar $20 \mathrm{~mm}$. D) Senftenbergia plumosa (Artis) Stur. Same as Opluštil et al. (2007, pl. VII, fig. 3). Kladno Coalfield. National Museum in Prague; scale bar $20 \mathrm{~mm}$. E) Oligocarpia sp. Kladno, Sládeček Museum in Kladno; scale bar $20 \mathrm{~mm}$. 

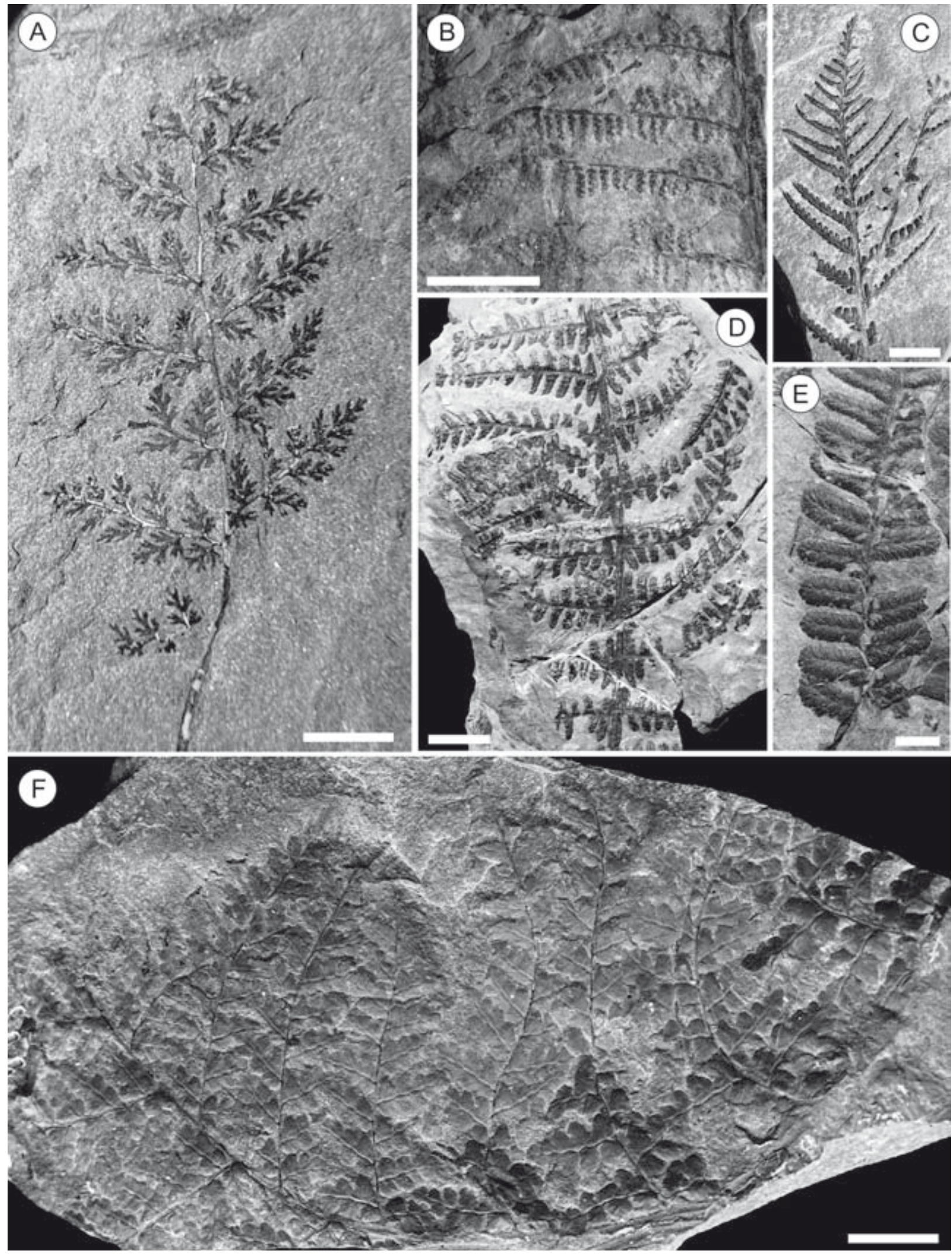

Figure 15. Ferns from the Mydlák. A) Zeilleria delicatula Kidston. Kladno Coalfield, Sládeček Museum in Kladno (Pa 918); scale bar $10 \mathrm{~mm}$. B) Corynepteris coralloides (Gutbier) Zeiller. Schoeller Mine, S. Opluštil collection; scale bar $20 \mathrm{~mm}$. C) Senftenbergia plumosa (Artis) Stur. Tuchlovice Mine, S. Opluštil collection; scale bar $10 \mathrm{~mm}$. D) Senftenbergia pennaeformis (Brongniart) Stur. Tuchlovice Mine, S. Opluštil collection; scale bar $10 \mathrm{~mm}$. E) Pecopteris abbreviata Brongniart. Max Mine, S. Opluštil collection; scale bar $5 \mathrm{~mm}$. F) Renaultia rotundifolia. Theodor Mine, J. Haldovský collection, scale bar $10 \mathrm{~mm}$. 

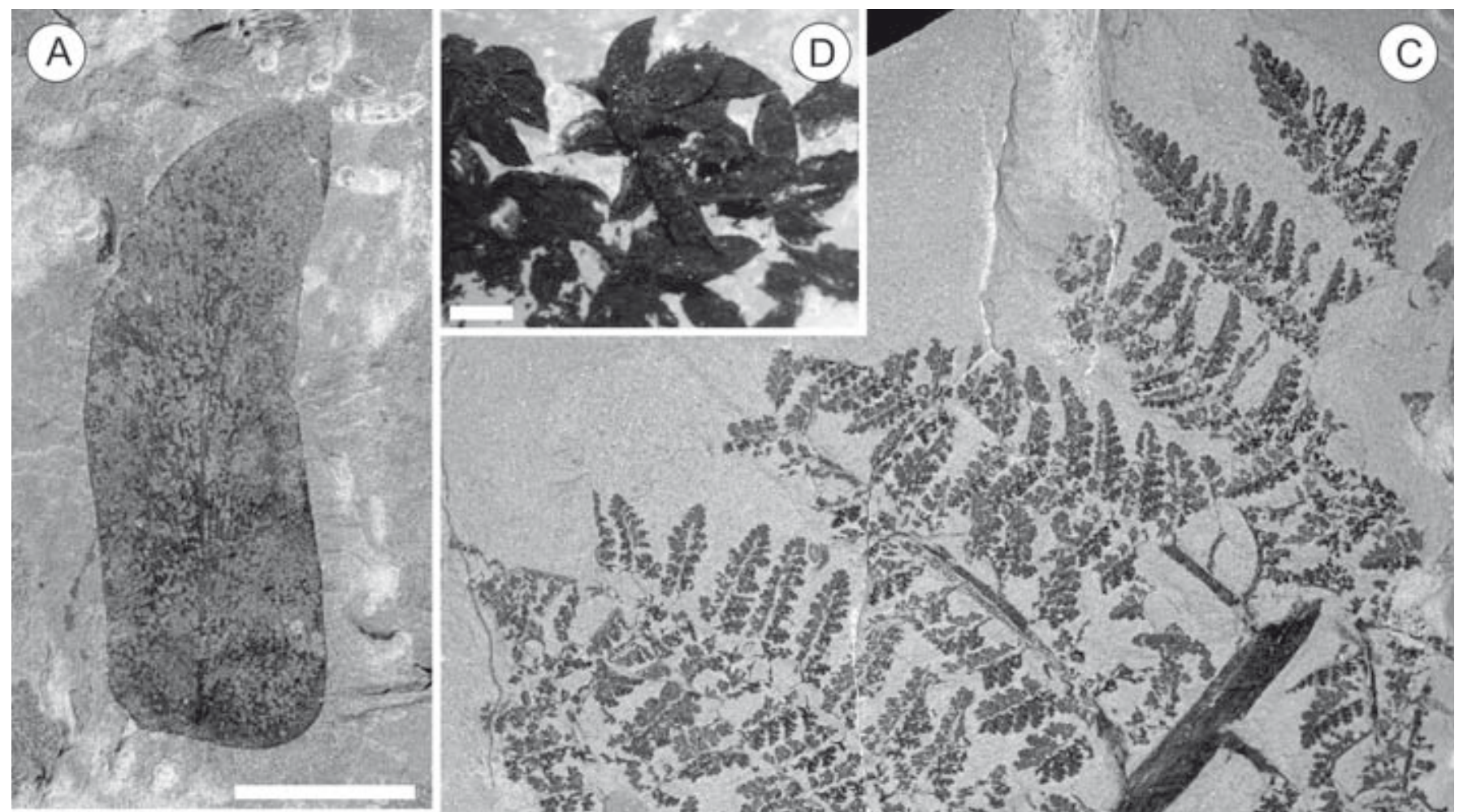

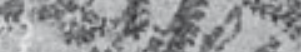
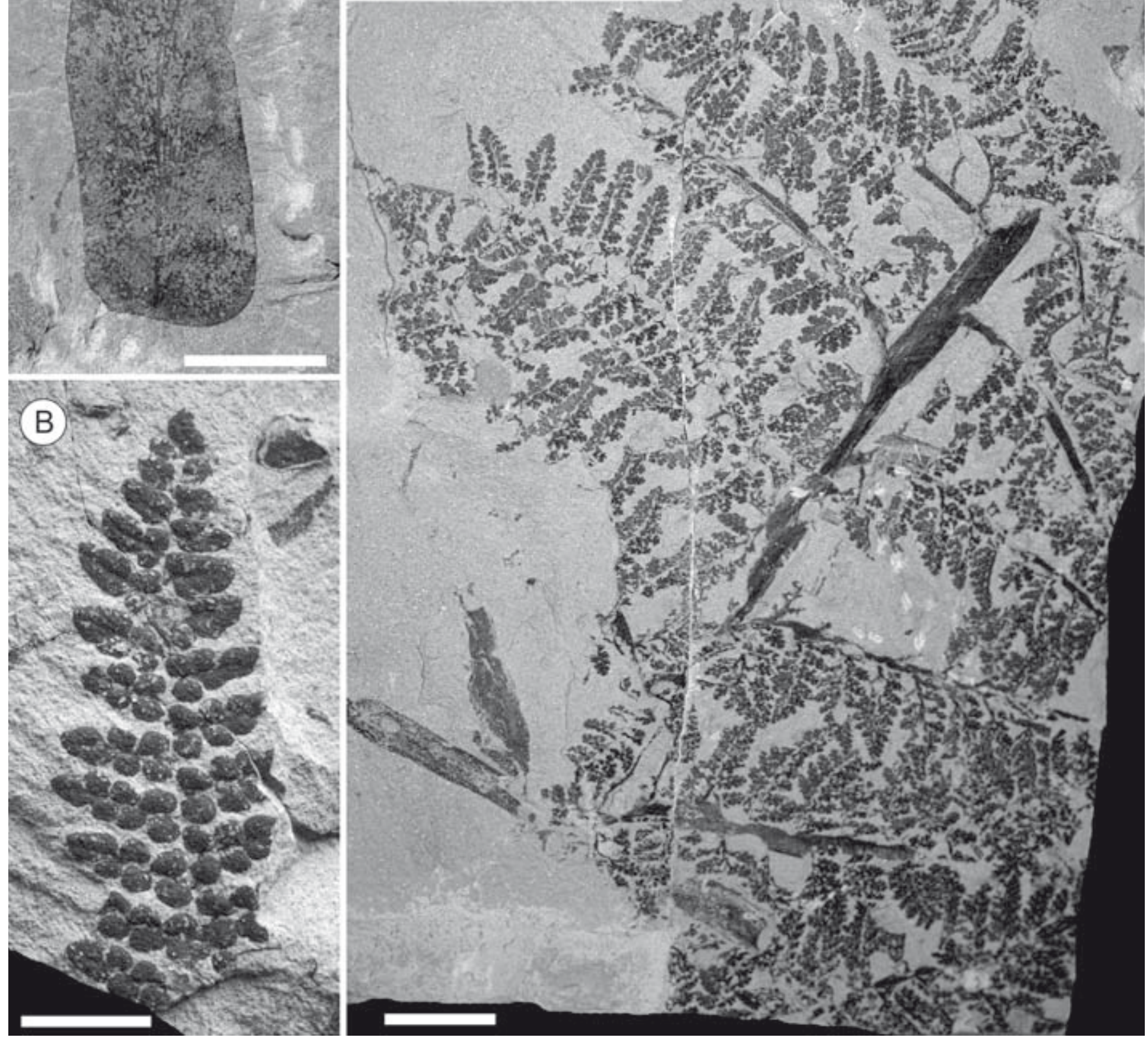

Figure 16. Pteridosperms from the Velká opuka. A) Linopteris neuropteroides Gutbier forma major Potonie. Theodor Mine, J. Haldovský collection; scale bar $10 \mathrm{~mm}$. B) Eusphenopteris cf. nummularia (Gutbier) Novik. Same as Opluštil et al. (2007, pl. VII, fig. 11). Kladno Coalfield. National Museum in Prague (E 6240); scale bar $10 \mathrm{~mm}$. C) Sphenopteris flexuosissima (Stur). Figured as Sphenopteris cf. crepinii in Opluštil et al. (2007, pl. VII, fig. 10). Kladno Coalfield. National Museum in Prague; scale bar $20 \mathrm{~mm}$. D) Details of pollen organs attached to Sphenopteris flexuosissima. Ronna Mine, S. Opluštil collection; scale bar $1 \mathrm{~mm}$. 


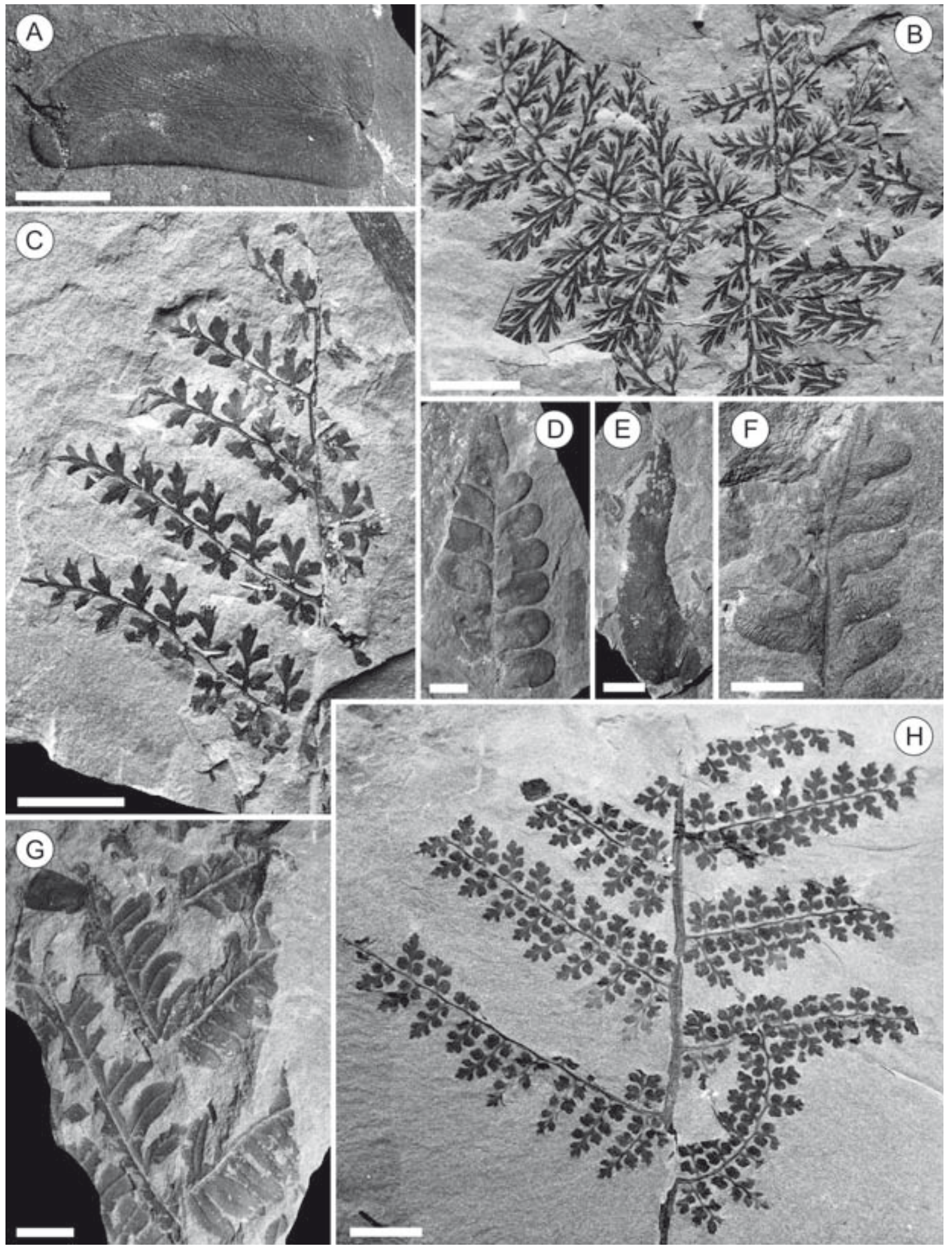

Figure 17. Pteridosperms from the Mydlák. A) Linopteris neuropteroides Gutbier forma major Potonié. Theodor Mine, J. Haldovský collection; scale bar 10 mm. B) Palmatopteris furcata (Brongniart) Potonié. Tuchlovice Mine, S. Opluštil collection; scale bar $20 \mathrm{~mm}$. C) Eusphenopteris sauveurii (Crépin) Simson-Scharold. Kladno Coalfield. National Museum in Prague (E 6242); scale bar $20 \mathrm{~mm}$. D) Mixoneura praeovata Němejc. Theodor Mine, J. Haldovský collection; scale bar $10 \mathrm{~mm}$. E) Macroneuropteris scheuchzeri (Hoffmann) Cleal, Shute \& Zodrow. Theodor Mine, J. Haldovský collection; scale bar 10 $\mathrm{mm}$. F) Alethopteris distantinervosa Wagner. Theodor Mine, J. Haldovský collection; scale bar $10 \mathrm{~mm}$. G) Alethopteris cf. serlii Brongniart. Tuchlovice Mine, S. Opluštil collection; scale bar $10 \mathrm{~mm}$. H) Eusphenopteris nummularia (Gutbier) Novik. Mayrau Mine, S. Opluštil collection; scale bar $20 \mathrm{~mm}$. 

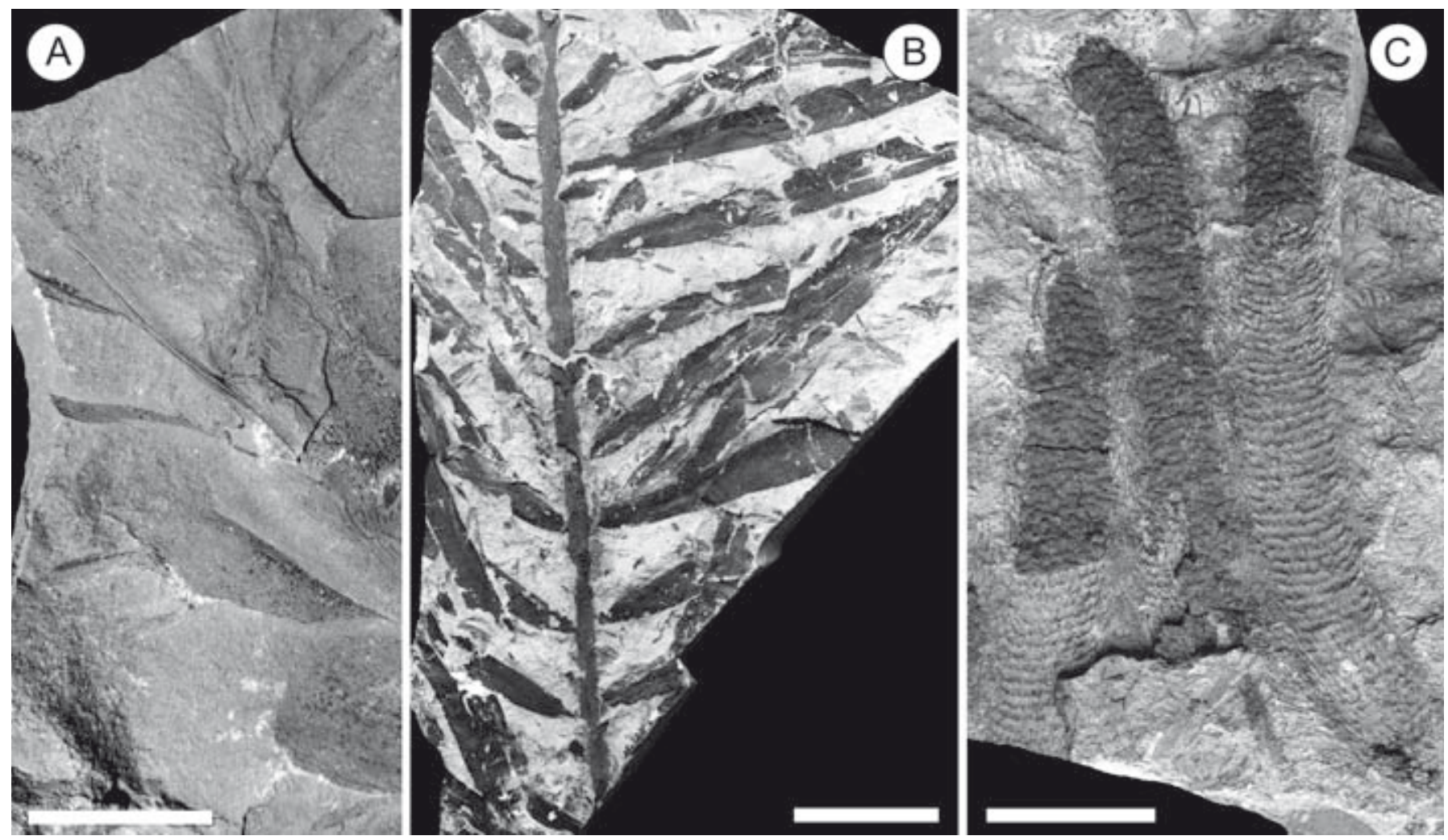

Figure 18. Additional Velká opuka species. A) Noeggerathia foliosa Sternberg. Kladno Coalfield, Sládeček Museum in Kladno; scale bar $30 \mathrm{~mm}$. B) Cordaites sp. Kladno Coalfield. National Museum in Prague; scale bar $50 \mathrm{~mm}$. C) Bowmanites sp. Schoeller Mine. National Museum in Prague; scale bar $20 \mathrm{~mm}$.

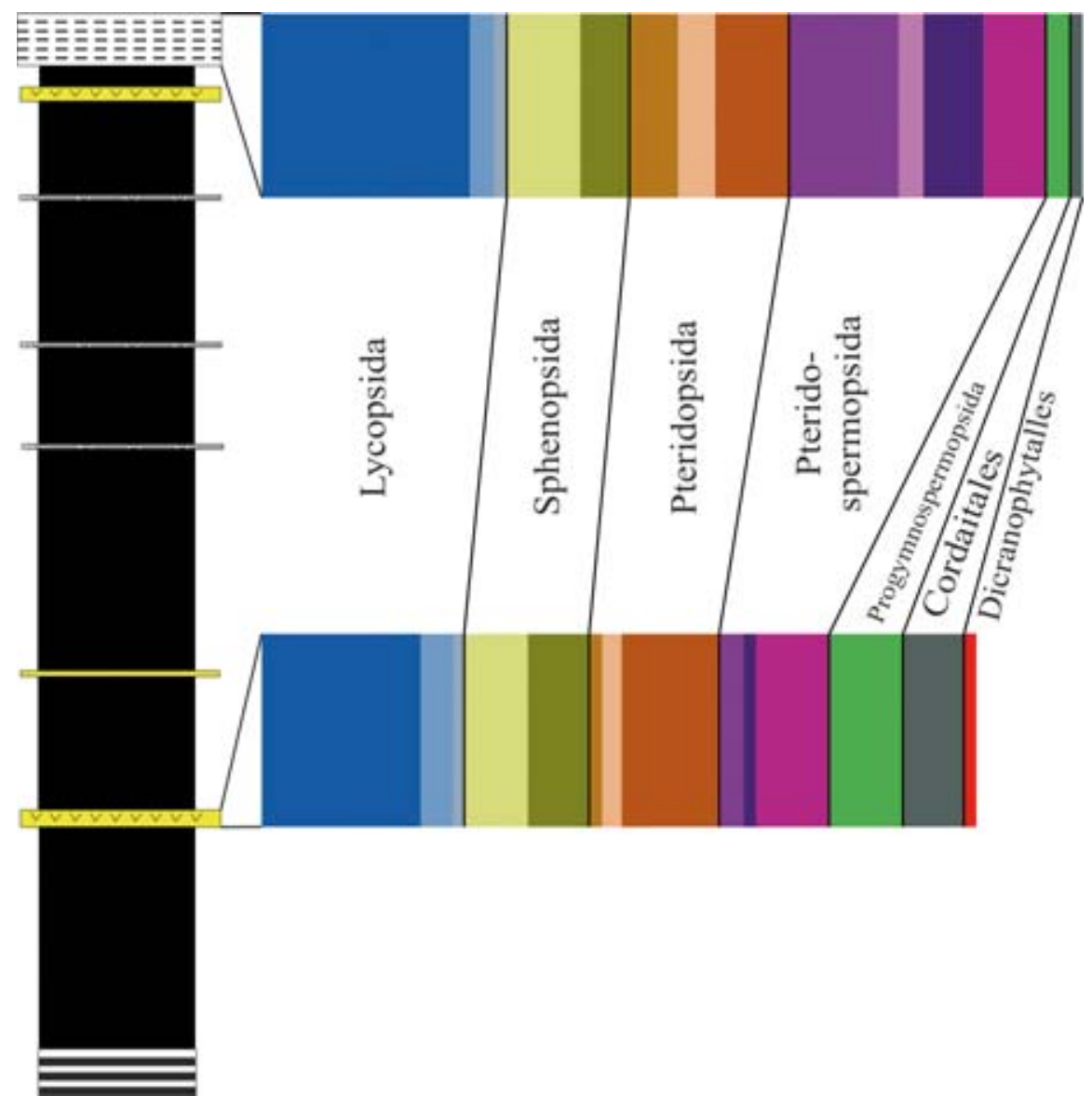

Figure 19. Vegetation patterns of the Velká opuka and Mydlák in the Kladno Coalfield. 


\section{REFERENCES}

Amerom, H.W.J. van 1975. Die eusphenopteridischen Pteridophyllen aus der Sammlung des Geologischen Bureaus in Heerlen, unter besonderer Berücksichtigung ihrer Stratigraphie bezüglich des Südlimburger Kohlenreviers. Mededelingen Rijks Geologische Dienst, Serie C-III-1, 7, 1-208.

Barthel, M. 2016. Die Rotliegendflora der Döhlen-Formation. Geologica Saxonica, Journal of Central European Geology, 61 (2), 105-238.

Barthel, M. \& Noll, R. 1999. On the growth habit of Dicranophyllum hallei Remy et Remy.

Veröffentlichungen Naturistorische Museum Schleusingen, 14, 59-64.

Bateman, R.M. 1991. Palaeoecology. In: Plant fossils in geological investigation. The Palaeozoic (ed. Cleal, C.J.). New York, Ellis Horwood Limited, 34-116.

Bateman, R.M., DiMichele, W.A. \& Willard, D.A. 1992. Experimental cladistic analysis of anatomically preserved arborescent lycopsids from the Carboniferous of Euramerica: an essay on paleobotanical phylogenetics. Annals of the Missouri Botanical Garden, 79 (3), 500-559.

Bek, J. \& Opluštil, S. 1998. Some lycopsid, sphenopsid and pteropsid fructifications and their miospores from the upper Carboniferous basins of the Bohemian Massif. Palaeontographica, Abt. B, 248, 127-161.

Bek, J. \& Opluštil, S. 2004. Palaeoecological constraints of some Lepidostrobus cones and their parent plants from the Late Palaeozoic continental basins of the Czech Republic. Review of Palaeobotany and Palynology, 131, 49-89; doi:10.1016/j.revpalbo.2004.02.008.

Bek, J. \& Opluštil, S. 2006. Six rare Lepidostrobus species from the Pennsylvanian of the Czech Republic and their bearing on the classification of lycospores. Review of Palaeobotany and Palynology, 139, 211-226; doi:10.1016/j.revpalbo.2006.01.003.

Bek, J. \& Šimůnek, Z. 2005. Revision of the cone genus Discinites from the Carboniferous continental basins of Bohemia. Palaeontology, 48 (6), 1377-1397; doi:10.1111/ j.1475-4983.2005.00516.x.

Bek, J., Libertín, M. \& Drábková, J. 2009a. Spencerites leismanii sp. nov., a new sub-arborescent compression lycopsid and its spores from the Pennsylvanian of the Czech Republic. Review of Palaeobotany and Palynology, 155, 116-132; doi:10.1016/j.revpalbo.2007.12.007.

Bek, J., Libertín, M. \& Drábková, J. 2009b. Selaginella labutae sp. nov., a new compression herbaceous lycopsid and its spores from the Kladno-Rakovník Basin, Bolsovian of the Czech Republic. Review of Palaeobotany and Palynology, 155, 101-115; doi:10.1016/j.revpalbo.2007.12.010.

Bek, J., Opluštil, S., Drábková, J. \& Pšenička, J. 2015. The sub-arborescent lycopsid Omphalophloios feistmantelii (O. Feistmantel) comb. nov. emend. from the Middle Pennsylvanian of the Czech Republic. Bulletin of Geosciences, 90 (1), 227-279; doi: 10.3140/bull. geosci.1505.
Bohor, B.F. \& Triplehorn, D.M. 1993. Tonsteins: Altered Volcanic-Ash Layers in Coal-Bearing Sequences. Geological Society of America Special Paper, 285, 1-45; doi:10.1130/SPE285-p1.

Brongniart, A. 1822. Sur la classification et la distribution des végétaux fossiles en général, et sur ceux des terrains de sédiment supérieur en particulier. Mémoires Muséum d'Histoire naturelle de Paris, 8, 203-348.

Brongniart, A. 1828-1838. Histoire des végétaux fossiles, ou Recherches botaniques et géologiques sur les végétaux renfermés dans les diverses couches du globe. Facsimile Edition W. Junk, Berlin (1915).

Burnham, R.J. 1994. Plant deposition in modern volcanic environments. Transactions of the Royal Society of Edinburgh: Earth Sciences, 84, 275-281; doi:10.1017/ S02635930000609X.

Burnham, R.J. \& Spicer, R.A. 1986. Forest Litter Preserved by Volcanic Activity at El Chichón, Mexico: A Potentially Accurate Record of the Pre-Eruption Vegetation. Palaios, 1, 158-161; doi:10.2307/3514509.

Čepek, L., Hynie, O., Kodym, O. \& Matějka, A. 1936. List Kladno 3952. Knihovna Státního geologického ústavu $\check{C} R$ 17, Praha, 1-144.

Cleal, C.J. 2005. The Westphalian macrofloral record from the cratonic central Pennines Basin, UK. Zeitschrift der Deutschen Gesellschaft für Geowissenschaften, 156 (3), 387-401; doi:10.1127/1860-1804/2005/0156-0387.

Cleal, C.J. \& Shute, C.H. 1995. A synopsis of neuropteroid foliage from the Carboniferous and Lower Permian of Europe. Bulletin of the British Museum (Natural History). Geology, 51, 1-52.

Cleal, C.J. \& Thomas, B.A. 2005. Palaeozoic tropical rainforests and their effect on global climates: is the past the key to the present? Geobiology, 3, 13-31; doi:10.1111/ j.1472-4669.2005.00043.x.

Cleal, C.J., Opluštil, S., Thomas, B.A. \& Tenchov, Y. 2010. Late Moscovian terrestrial biotas and palaeoenvironments of Variscan Euramerica. Netherlands Journal of Geosciences, 88, 181-278; doi:10.1017/S0016774600000846.

Cleal, C.J., Uhl, D., Cascales-Miñana, B., Thomas, B.A., Bashforth, A.R., King, S.C. \& Zodrow, E.L. 2012. Plant biodiversity changes in Carboniferous tropical wetlands. Earth Science Reviews, 114, 124-155; doi:10.1016/j. earscirev.2012.05.004.

Corda, A.J. 1845. Flora Protogaea. Beiträge zur Flora der Vorwelt. Calvary and Co., Berlin.

Corsin, P. 1937. Contribution à l'étude des Fougères Anciennes du Groupe des Inversicaténales. G. Sautai, Lille.

Davies, D. 1929. Correlation and palæontology of the Coal Measures in east Glamorganshire. Philosophical Transactions of the Royal Society of London, Series B, 217, 91-153.

Dennis, R.L. 1974. Studies of Paleozoic ferns: Zygopteris from the Middle and Upper Pennsylvanian of the United States. Palaeontographica, Abt. B, 148, 95-136.

DiMichele, W.A. 2014. Wetland-Dryland Vegetational Dynamics in the Pennsylvanian Ice Age Tropics. International Journal of Plant Sciences, 175 (2), 123-164. 
DiMichele, W.A. \& Bateman, R.M. 1992. Diaphorodendraceae, fam. nov. (Lycopsida: Carboniferous): systematics and evolutionary relationships of Diaphorodendron and Synchysidendron, gen. nov. American Journal of Botany, 79 (6), 605-617.

DiMichele, W.A. \& Falcon-Lang, H.J. 2011. Pennsylvanian "fossil forest" in growth position ( $\mathrm{T}^{0}$ assemblages): origin, taphonomic bias and palaeoecological insights. Journal of the Geological Society, London, 168, 585-605; doi:10.1144/0016-76492010-103.

DiMichele, W.A. \& Phillips, T.L. 1994. Paleobotanical and paleoecological constraints on models of peat formation in the Late Carboniferous of Euramerica. Palaeogeography, Palaeoclimatology, Palaeoecology, 106, 39-90; doi:10.1016/0031-0182(94)90004-3.

DiMichele, W.A. \& Phillips, T.L. 2002. The ecology of Paleozoic ferns. Review of Palaeobotany and Palynology, 119, 143-159; doi:10.1016/S0034-6667(01)00134-8.

DiMichele, W.A., Phillips, T.L. \& McBrinn, G.E. 1991. Quantitative Analysis and Paleoecology of the Secor Coal and Roof-Shale Floras (Middle Pennsylvanian, Oklahoma). Palaios, 6, 390-409; doi: $10.2307 / 3514965$

DiMichele, W.A., Phillips, T.L. \& Nelson, W.J. 2002. Place vs. time and vegetational persistence: a comparison of four tropical mires from the Illinois Basin during the height of the Pennsylvanian Ice Age. International Journal of Coal Geology, 50, 43-72; doi: 10.1016/S01665162(02)00113-1.

DiMichele, W.A., Cecil, C.B., Montañez, I.P. \& Falcon-Lang, H.J. 2010. Cyclic changes in Pennsylvanian paleoclimate and effects on floristic dynamics in tropical Pangaea. International Journal of Coal Geology, 83, 329-344; doi:10.1016/j.coal.2010.01.007.

DiMichele, W.A., Behrensmeyer, A.K., Olszewski, T.D., Labandeira, C.C., Pandolfi, J.M., Wing, S.L. \& Bobe, R. 2004. Long-Term Stasis in Ecological Assemblages: Evidence from the Fossil Record. Annual Review of Ecology, Evolution, and Systematics, 35, 285-322; doi:10.1146/annurev.ecolsys.35.120202.110110.

Drábková, J., Bek, J. \& Opluštil, S. 2004. The first compression fossils of Spencerites (Scott) emend., and its isospores, from the Bolsovian (Pennsylvanian) of the Kladno-Rakovník and Radnice basins, Czech Republic. Review of Palaeobotany and Palynology, 130, 59-88; doi:10.1016/j.revpalbo.2004.01.004.

Eggert, D.A. \& Delevoryas, T. 1967. Studies of Paleozoic ferns: Sermaya, gen. nov. and its bearing on filicalean evolution in the Paleozoic. Palaeontographica, Abt. B, 120, 169-180.

Ettingshausen, C. 1854. Die Steinkohlenflora von Radnitz in Böhmen. Abhandlungen der kaiserlichen-königlichen geologischen Reichsanstalt, Bd. II, 3 Abt. 3, 1-74.

Falcon-Lang, H. 2004. Pennsylvanian tropical rain forests responded to glacial-interglacial rhythms. Geology, 32, 689-692; doi:10.1130/G20523.1.

Feistmantel, O. 1874. Versteinerungen der böhmischen Ablagerungen. Verlag von Theodor Fischer, Cassel, 1-156.
Galtier, J. 1997. Coal-ball floras of the Namurian-Westphalian of Europe. Review of Palaeobotany and Palynology, 95, 51-72; doi:10.1016/S0034-6667(96)00027-9.

Galtier, J. 2008. A new look at the permineralized flora of Grand-croix (Late Pennsylvanian, Saint-Etienne basin, France). Review of Palaeobotany and Palynology, 152, 129-140; doi:10.1016/j.revpalbo.2008.04.007.

Galtier, J. \& Phillips, T.L. 2014. Evolutionary and ecological perspectives of Late Paleozoic ferns. Part III. Anachoropterid ferns (including Anachoropteris, Tubicaulis, the Sermayaceae, Kaplanopteridaceae and Psalixochlaenaceae). Review of Palaeobotany and Palynology, 205, 31-73; doi:10.1016/j.revpalbo.2014.02.012.

Galtier, J. \& Scott, A.C. 1979. Studies of Paleozoic ferns: On the genus Corynepteris. A redescription of the type and some other European species. Palaeontographica, Abt. B, 170, 81-125.

Gastaldo, R.A. 1987. Confirmation of Carboniferous clastic swamp communities. Nature, 326, 871-896; doi:10.1038/326869a0.

Gastaldo, R.A. \& Demko, T.M. 2011. The Relationship Between Continental Landscape Evolution and the Plant-Fossil Record: Long Term Hydrologic Controls on Preservation. In: Taphonomy; Second Edition. Process and Bias Through Time (eds. Allison, P.A. \& Bottjer, D.J.). Topics in Geobiology, 32, 249-286.

Gastaldo R.A., Pfefferkorn, H.W. \& DiMichele, W.A. 1995. Taphonomic and sedimentologic characterization of roofshale floras. Geological Society of America, Memoir 185, 341-352; doi:10.1130/MEM185-p341.

Gastaldo, R.A., Stevanović-Walls, I.M., Ware, W.N. \& Greb, S.F. 2004. Community heterogeneity of Early Pennsylvanian peat mires. Geology, 32 (8), 693-696; doi:10.1130/G20515.1.

Gothan, W. \& Gimm, W. 1930. Neuere Beobachtungen und Betrachtungen über die Flora des Rotliegenden von Thüringen. Arbeiten Institut für Paläobotanik und Petrographie der Brennsteine, 2 (1), 38-77.

Greb, S.F., DiMichele, W.A. \& Gastaldo, R.A. 2006. Evolution and importance of wetlands in earth history. In: Wetlands through time (eds. Greb, S.F. \& DiMichele, W.A.). Geological Society of America, Special Paper 399, 1-40; doi:10.1130/2006.2399(01).

Havlena, V. 1953. Neuropteridy českého karbonu a permu. Rozpravy Ústředního ústavu geologického, 16, 1-168.

Havlena, V. 1961. Die flöz nahe und flöz fremde flor des oberschlesischen Namurs A und B. Palaeontographica, Abt. B, 180, 22-38.

Havlena, V. 1964. Geologie uhelných ložisek, 2. Nakladatelství Československé akademie věd, 1-437.

Holmes, J.C. \& Fairon-Demaret, M. 1984. A new look at the flora of the Bouxharmont coal balls from Belgium. Annales de la Société Géologique de Belgique, 107, 73-87.

Jennings, J.R. \& Eggert, D.A. 1977. Preliminary report on permineralized Senftenbergia from the Chester Series of Illinois. Review of Palaeobotany and Palynology, 24, 221-225; doi:10.1016/0034-6667(77)90035-5. 
Lesnikowska, A.D. 1989. Anatomically Preserved Marattiales from Coal Swamps of the Desmoinesian and Missourian of the Midcontinent United States: Systematics, Ecology and Evolution. PhD Thesis, University of Illinois at Urbana-Champaign, USA, 1-454 (unpublished).

Lindley, J. \& Hutton, W. 1831-1837. The Fossil Flora of Great Britain; or, Figures and Descriptions of the Vegetable Remains found in a Fossil State in this Country. James Ridgway and Sons, London.

Mašek, J. 1973. Volcanic products of the Central Bohemian Carboniferous. Sborník Geologických Vëd, Geologie, 24, 73-104 (in Czech with English abstract).

Mašek, J. \& Pešek, J. 1979. Opuky of the Main Kladno Coal in the Kačice deposit of the Klement Gottwald Mine in the Kladno area. Uhlí, 27 (2), 55-61.

Němejc, F. 1929. O některých nových nálezech ve středočeských uhelných pánvích. Rozpravy II. tř. České akademie věd, 39, 33, 1-8.

Němejc, F. 1936. Studies on the Alethopterids of the Permocarboniferous of Central Bohemia (with remarks on forms collected in other Bohemian coal districts). Věstnik Královské České Společnosti Nauk, 2, 1-18,

Němejc, F. 1941. Further indications of the type Discinites in addition to some remarks on the Archaeopteriden of the Middle Bohemian coal basins. Mitteilungen der Tschechischen Akademie der Wissenschaften, 19, 1-13.

Němejc, F. 1946. Contributions to the stratigraphy of the Carboniferous and Permian of Bohemia. Sbornik státního geologického ústavu Československé republiky, 13, $207-$ 257.

Němejc, F. 1947. The Lepidodendraceae of the coaldistricts of Central Bohemia. Sbornik Národního Musea, Geologia et palaeontologia, III B (2), 45-87.

Němejc, F. 1953. Taxonomical studies on the fructification of the Calamitacea collected in the coal districts of central Bohemia. Sbornik Národního Musea, Geologia et palaeontologia, IX B (1), 1-62.

Němejc, F. 1954. Taxonomical studies on the strobili of the Lepidodendraceae of the coal district of central Bohemia. Sborník Národního Musea, Geologia et palaeontologia, X B (5), 1-84.

Opluštil, S. 2003. Sedimentation and paleogeography of the Radnice Member Duckmantian/ Bolsovian) in the Kladno part of the Kladno-Rakovník Basin. Sbornik Západočeského Muzea Plzen̆, Přiroda, 102, 1-83.

Opluštil, S. 2005a. Evolution of the Middle Westphalian river valley drainage system in central Bohemia (Czech Republic) and it palaeogeographic implication. Palaeogeography, Palaeoclimatology, Palaeoecology, 222, 223-58; doi:10.1016/j.palaeo.2005.03.016.

Oplusstil, S. 2005b. The effect of paleotopography, tectonics and sediment supply on quality of coal seams in continental basins of central and western Bohemia (Westphalian), Czech Republic. International Journal of Coal Geology, 64, 173-203; doi:10.1016/j.coal.2005.03.022. Opluštil, S., Sýkorová, I. \& Bek, J. 1999. Sedimentology, coal petrology and palynology of the Radnice Member in the S-E part of the Kladno-Rakovník Basin, central Bohemia
(Bolsovian). Acta Universitatis Carolinae, Geologica, 43 (4), 599-623.

Opluštil, S., Pšenička, J., Libertín, M. \& Šimůnek, Z. 2007. Vegetation patterns of Westphalian and Lower Stephanian mire assemblages preserved in tuff beds of the continental basins of Czech Republic. Review of Palaeobotany and Palynology, 143, 107-154; doi:10.1016/j.revpalbo.2006.06.004.

Opluštil, S., Schmitz, M., Cleal, C.J. \& Martínek, K. 2016. A review of the Middle-Late Pennsylvanian west European regional substages and floral biozones, and their correlation to the Geological Time Scale based on new U-Pb ages. Earth Science Reviews, 154, 301-335; doi:10.1016/j.earscirev.2016.01.004.

Opluštil, S., Šimůnek, Z., Zajíc, J. \& Mencl, V. 2013. Climatic and biotic changes around the Carboniferous/Permian boundary recorded in the continental basins of the Czech Republic. International Journal of Coal Geology, 119, 114-151; doi:10.1016/j.coal.2013.07.014.

Opluštil, S., Pšenička, J., Libertín, Bek, J., Dašková, J., Šimůnek, Z. \& Drábková, J. 2009a. Composition and structure of an in situ Middle Pennsylvanian peat-forming plant assemblage in volcanic ash, Radnice Basin (Czech Republic). Palaios, 24, 726-746; doi:10.2110/palo.2008.p08-128r.

Opluštil, S., Pšenička, J., Libertín, M., Bashforth, A.R., Šimůnek, Z., Drábková, J. \& Dašková, J. 2009b. A Middle Pennsylvanian (Bolsovian) peat-forming forest preserved in situ in volcanic ash of the Whetstone Horizon in the Radnice Basin, Czech Republic. Review of Palaeobotany and Palynology, 155, 234-374; doi:10.1016/j.revpalbo.2009.03.002.

Opluštil, S., Pšenička, J., Bek, J., Wang. J., Feng, Z., Libertín, M., Šimůnek, Z., Bureš, J. \& Drábková, J. 2014. T ${ }^{0}$ peat-forming plant assemblage preserved in growth position by volcanic ash-fall: A case study from the Middle Pennsylvanian of the Czech Republic. Bulletin of Geosciences, 89 (4), 773-818.

Orlov, A. 1942. Sedimenty uhelné sousloje v kladenské kamenouhelné pánvi. Zprávy Geologického Ústavu pro Čechy a Moravu, 18, 221-253.

Peppers, R.A. 1996. Palynological correlation of major Pennsylvanian (Middle and Upper Carboniferous) chronostratigraphic boundaries in the Illinois and other coal basins. Geological Society of America Memoir, 188, 1-119; doi:10.1130/0-8137-1188-6.1.

Pešek, J. 1994. Carboniferous of central and western Bohemia (Czech Republic). Czech Geological Survey, Prague, 1-60.

Pešek, J. 2004. Late Palaeozoic limnic basis and coal deposits of the Czech Republic. Folia Musei Rerum Naturalium Bohemiae Occidentalis, Geologica, 1, 1-188.

Phillips, T.L. 1974. Evolution of vegetative morphology in Coenopterid ferns. Annals of Missouri Botanical Garden, 61, 427-461.

Phillips, T.L. 1981. Stratigraphic occurrences and vegetational patterns of Pennsylvanian pteridosperms in Euramerican coal swamps. Review of Palaeobotany and Palynology, 32, 5-26; doi:10.1016/0034-6667(81)90073-7. 
Phillips, T.L. \& Galtier, J. 2005. Evolutionary and ecological perspectives of Late Paleozoic ferns. Part I. Zygopteridales. Review of Palaeobotany and Palynology, 135, 165-203.

Phillips, T.L. \& Galtier, J. 2011. Evolutionary and ecological perspectives of late Paleozoic ferns: Part II. The genus Ankyropteris and the Tedeleaceae. Review of Palaeobotany and Palynology, 164, 1-29; doi:10.1016/j. revpalbo.2010.07.004.

Phillips T.L., Peppers, R.A. \& DiMichele, W.A. 1985. Stratigraphic and interregional changes in Pennsylvanian coal-swamp vegetation: Environmental inferences. In: Paleoclimatic Controls on Coal Resources of the Pennsylvanian System of North America (eds. Phillips, T.L. \& Cecil, C.B.). International Journal of Coal Geology, 5, 43-109.

Pšenička, J. \& Bek, J. 2009. Description of synangia and spores of the holotype of the Carboniferous fern Lobatopteris miltoni, with taxonomic comments. Review of Palaeobotany and Palynology, 155, 133-44; doi:10.1016/j.revpalbo.2007.12.005.

Pšenička, J., Bek, J., Cleal, C.J., Wittry, J. \& Zodrow, E. 2009. Description of synangia and spores of the holotype of the Carboniferous fern Lobatopteris miltoni, with taxonomic comments. Review of Palaeobotany and Palynology,155,133-144; doi:10.1016/j. revpalbo.2007.12.005.

Rössler, R. 2000. The late Palaeozoic tree fern Psaronius - an ecosystem unto itself. Review of Palaeobotany and Palynology, 108, 55-74; doi:10.1016/S00346667(99)00033-0.

Rössler, R. \& Barthel, M. 1998. Rotliegend taphocoenoses preservation favoured by rhyolithic explosive volcanism. Freiberger Forschungshefte, Paläontologie, Stratigraphie, Fazies, C 474 (6), 59-101.

Scott, A.C., Mattey, D. \& Howard, R. 1996. New data on the formation of Carboniferous Coal Balls. Review of Palaeobotany and Palynology, 93, 317-331; doi:10.1016/0034-6667(95)00132-8.

Šetlík, J. 1977. Results on recent investigation on the Carboniferous flora of Bohemia. In: Symposium on Carboniferous Stratigraphy (eds. Holub, V. \& Wagner, R.H.). Czechoslovakian Geological Survey, Prague, 315-340.

Šimůnek, Z. 1989. Varieties of the species Alethopteris grandinioides Kessler from the Kladno Formation (Westphalian C, D, Bohemia). Časopis pro mineralogii a geologii, 33, 381-394.

Šimůnek, Z. 2007. New classification of the genus Cordaites from the Carboniferous and Permian of the Bohemian Massif based on cuticle micromorphology. Acta Musei nationalis Pragae, Series B, Historia Naturalis, 62 (3-4), 97-210.

Šimůnek, Z. \& Bek, J. 2003. Noeggerathiaceae from the Carboniferous basins of the Bohemian Massif. Review of Palaeobotany and Palynology, 125, 249-284; doi:10.1016/ S0034-6667(03)00004-6.

Šimůnek, Z. \& Cleal, C.J. 2002. The taxonomy of middle Westphalian medullosalean foliage known as 'Alethopteris grandinioides early form' from the Central and Western
Bohemian basins. Bulletin of the Czech Geological Survey, 77 (1), 61-64.

Šimůnek, Z. \& Cleal, C.J. 2011. Imparipinnate neuropterid foliage (Medullosales) from the Middle Westphalian of Central Bohemia, Czech Republic. Review of Palaeobotany and Palynology, 166, 163-201; doi:10.1016/j. revpalbo.2011.05.005.

Šimůnek, Z. \& Florjan, S. 2013. The Pennsylvanian cordaitalean dispersed cuticles from the Upper Silesian Basin (Poland). Review of Palaeobotany and Palynology, 197, 26-49; doi: 10.1016/j.revpalbo.2013.04.006.

Šimůnek, Z. \& Haldovský, J. 2015. Contribution to the knowledge of Cordaites species from the KladnoRakovník Basin, Middle Pennsylvanian (Bolsovian) Czech Republic. Geologia Croatica, 68, 2, 93-111; doi:10.4154/ gc.2015.11.

Sternberg, K.M. von 1820-1825. Versuch einer geognostischbotanischen Darstellung der Flora der Vorwelt. Parts 1-2 (1820-1821), F. Fleischer, Leipzig; Parts 3-4 and Tentamen (1823-1825), E. Brenck's Wittwe, Regensburg; Parts 5-6 (1833), Spurny, Prague.

Stubblefield, S.P., Taylor, T.N. \& Daghlina, C.P. 1982. Compressed plants from the Lower Pennsylvanian of Kentucky (U.S.A.). I. Crossotheca kentuckiensis n. sp. Review of Palaeobotany and Palynology, 36, 197-204; doi:10.1016/0034-6667(82)90019-7.

Tabor, N.J., Romanchock, C.M., Looy, C.V., Hotton, C.L., DiMichele, W.A. \& Chaney, D.S. 2013. Conservatism of Late Pennsylvanian vegetational patterns during shortterm cyclic and long-term directional environmental change, western equatorial Pangea. In: Palaeozoic Climate Cycles: Their Evolutionary and Sedimentological Impact (eds. Gąsiewicz, A. \& Słowakiewicz, M.). Geological Society, London, Special Publication 376, 201-234.

Taylor, T.N., Taylor, E.L. \& Krings, M. 2009. Paleobotany. The Biology and Evolution of Fossil Plants. Second Edition. Academic Press, Elsevier, 1-1230.

Wagner, R.H. 1958. Some Stephanian pecopterids from NW Spain. Mededelingen Geologische Stichting, Nieuwe Series, 12, 5-23.

Wagner, R.H. 1968. Upper Westphalian and Stephanian species of Alethopteris from Europe, Asia Minor and North America. Mededelingen Rijks Geologische Dienst, C III-1, 6, 1-318.

Wagner, R.H. 1984. Megafloral zones of the Carboniferous. Compte Rendu $9^{\circ}$ Congrès International de Stratigraphie et Géologie du Carbonifère, Washington and ChampaignUrbana 1979, 2, 109-134.

Wagner, R.H. 1989. A late Stephanian forest swamp with Sporangiostrobus fossilized by volcanic ash fall in the Puertollano Basin, central Spain. International Journal of Coal Geology, 12, 523-552; doi:10.1016/01665162(89)90064-5.

Wagner, R.H. \& Álvarez-Vázquez, C. 2015. A coastal forest swamp dominated by Omphalophloios C. D. White, in the Autunian (uppermost Stephanian) of Puertollano, south-central Spain. Palaeontographica, Abt. B, 292 (1-3), 33-77. 
Wagner, R.H. \& Álvarez-Vázquez, C. 2016. A reappraisal of Pecopteris miltonii (Artis) Brongniart, a midWestphalian (Early-Mid Pennsylvanian) fern. Proceedings of the Yorkshire Geological Society, 61 (1); doi:10.1144/ pygs2015-368.

Wang, J., Pfefferkorn, H.W., Zhang, Y. \& Feng, Z. 2012. Permian vegetational Pompeii from Inner Mongolia and its implications for landscape paleoecology and paleobiogeography of Cathasia. PNAS, 1-6.

Weithofer, K.A. 1896. Die geologischen Verhältnisse des Bayer-Schachtes und benachbarten Teiles der Pilsner Kohlenmulde. Österreiche Zeitschrift für Berg- und Hüttenwesen, 44, 317-21, 331-5, 345-9, 355-7.

Weithofer, K.A. 1902. Geologische Skizze des KladnoRakonitzer Kohlenbeckens. Verhandlungen der Geologischen Reichsanstalt, 399-420.
White, D. 1912. The characters of the fossil plant Gigantopteris Schenk and its occurrence in North America. Proceedings of the U.S. National Museum, 41, 493-516.

Žák, J., Verner, K., Janoušek, V., Holub, F.V., Kachlík, V., Finger, F., Hajná, J., Tomek, F., Vondrovic, L. \& Trubač, J. 2014. A plate-kinematic model for the assembly of the Bohemian Massif constrained by structural relationships around granitoid plutons. In: The Variscan Orogeny: Extent, Timescale and the Formation of the European Crust (eds. Schulmann, K., Martínez Catalán, J.R., Lardeaux, J.M., Janoušek, V. \& Oggiano, G.), Geological Society London, Special Publications, 405, 169-196; doi:10.1144/SP405.9.

Zeiller, R. 1899. Étude sur la Flore Fossile du Bassin d'Héraclée. Mémoires de la Société Géologique de France, Paléontologie, 21, 1-99. 